\title{
The genetic and epigenetic alterations in human hepatocellular carcinoma: a recent update
}

\author{
Ming Liu, Lingxi Jiang, Xin-Yuan Guan ${ }^{\bowtie}$ \\ Department of Clinical Oncology, University of Hong Kong, Hong Kong, China \\ $\triangle$ Correspondence: xyguan@hkucc.hku.hk (X.-Y. Guan) \\ Received March 18, 2014 Accepted April 13, 2014
}

\begin{abstract}
Hepatocellular carcinoma (HCC) is one of the most frequent human malignancies worldwide with very poor prognosis. It is generally accepted that the progression of HCC is a long-term process with accumulation of multiple genetic and epigenetic alterations, which further lead to the activation of critical oncogenes or inactivation of tumor suppressor genes. HCC is characterized with multiple cancer hallmarks including their ability to proliferate, anti-apoptosis, invade, metastasis, as well as the emerging features such as stem cell properties and energy metabolic switch. The irreversible alterations at genetic level could be detected as early as in the pre-neoplastic stages and accumulate during cancer progression. Thus, they might account for the cancer initiating steps and further malignant transformation. In addition to genetic alterations, epigenetic alterations can affect the cancer transcriptome more extensively. Alterations in DNA methylation, histone modification, miRNAs, RNA editing, and IncRNAs might result in disrupted gene regulation networks and substantially contribute to HCC progression. In this review, the genetic and epigenetic alterations which significantly contribute to the malignant capabilities of HCC will be updated and summarized in detail. Further characterization of those critical molecular events might better elucidate the pathogenesis of HCC and provide novel therapeutic targets for treatment of this deadly disease.
\end{abstract}

KEYWORDS hepatocellular carcinoma (HCC), cancer hallmarks, genetic regulation, epigenetic regulation,

therapeutic targets, $\mathrm{HCC}$ progression

\section{INTRODUCTION}

Hepatocellular carcinoma (HCC) is one of the most frequent human malignancies worldwide. It is the sixth most prevalent cancer in the world and the third leading cause of cancerrelated mortality (Parkin et al., 2005). The prevalence of $\mathrm{HCC}$ varies markedly in different regions. The highest incidence of HCC was found in Asia-pacific area $(>20 / 100,000)$, while low incidence was found in Northern Europe and Northern America $(<5 / 100,000)$ (Venook et al., 2010). China is a typical high-risk region which may account for more than $50 \%$ of HCC cases in the world (Yuen et al., 2009). The uneven distribution of HCC incidence among different geographic regions suggests that multiple genetic and environmental factors may interplay in the progression of this disease. Almost $70 \%-90 \%$ of $\mathrm{HCC}$ patients accompany with liver cirrhosis, which is believed to be the most important risk factor for HCC (Fattovich et al., 1997). Thus, all levels of viral infection, liver cytotoxicity, chronic inflammation which can lead to liver cirrhosis are important risk factors in the development of HCC (El-Serag and Rudolph, 2007).

It is widely accepted that carcinogenesis is a multi-step process with accumulation of genetic alterations in critical genes which regulate cell proliferation, growth, survival, apoptosis, adhesion, and metabolism (Vogelstein and Kinzler, 1993). The stepwise accumulation of genetic alterations in oncogenes and tumor suppressor genes will transform a normal cell and finally leads to carcinogenesis (Farber, 1984). The pathogenesis of HCC is also believed to be a long-term process which begins from the pre-malignant stage to the dysplastic stage and finally proceeds to the malignant stage (Thorgeirsson and Grisham, 2002). Better understanding of the genetic and epigenetic changes and their interactions at all the stages during $\mathrm{HCC}$ progression 


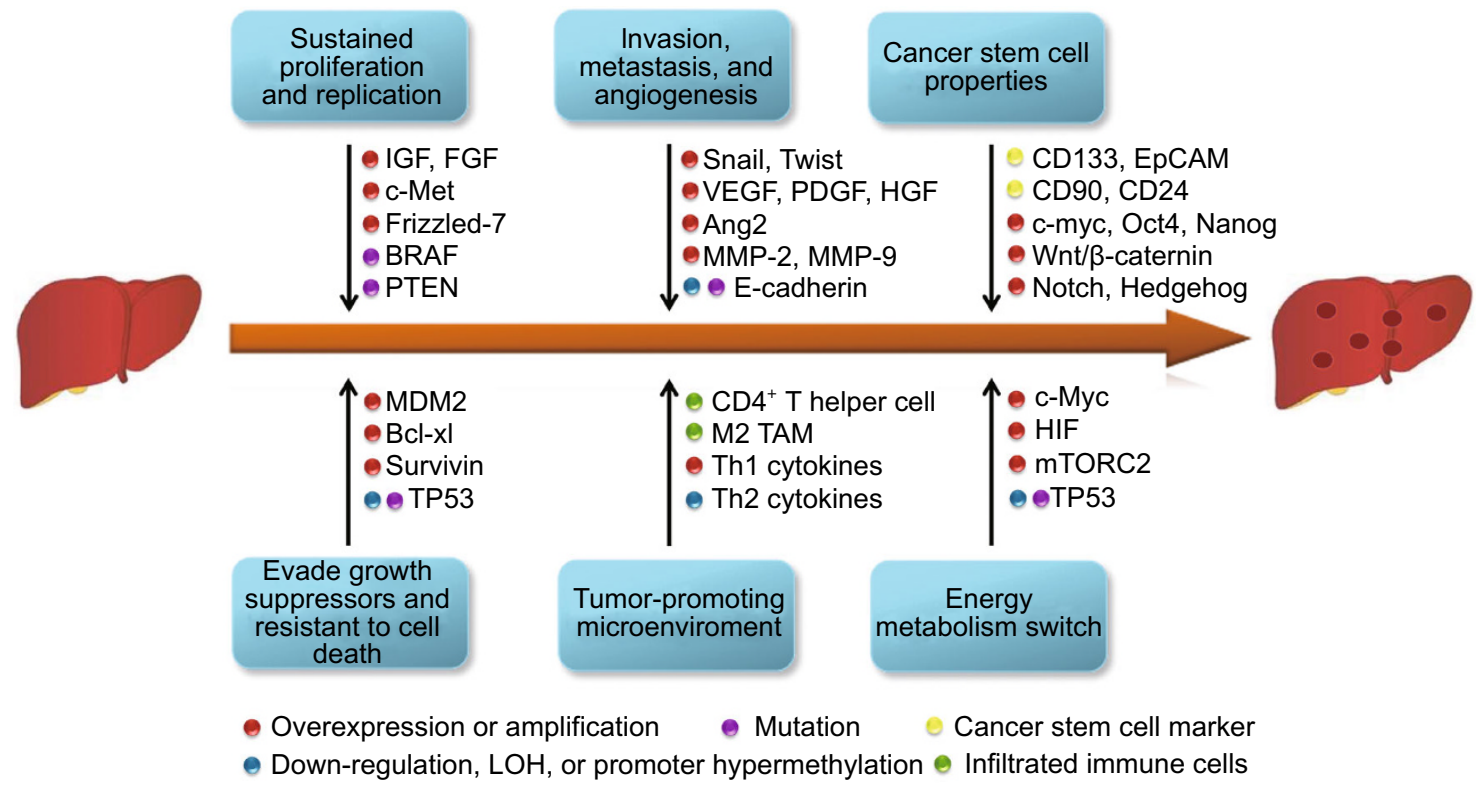

Figure 1. Multiple cancer hallmarks and the underlying molecular alterations in the progression of HCC. The progression of $\mathrm{HCC}$ is a multi-step process, which is characterized by several cancer hallmarks including sustained cell proliferation, evading growth suppressors, resistant to cell death, invasion, metastasis, angiogenesis, and deregulated energy metabolism. Multiple cellular and molecular alterations such as amplification or overexpression of oncogenes, hypermethylation or mutation of tumor suppressor genes, activation of cancer stem cells, and infiltration of immune cells, contribute to the malignant transformation of HCC.

will greatly facilitate to elucidate the pathogenesis of HCC. In this review, we summarize the current knowledge of genetic and epigenetic alterations in the progression of HCC.

\section{HALLMARKS OF HUMAN HEPATOCELLULAR CARCINOMA}

For decades, scientists are trying to unveil the underlied molecular mechanisms of cancer initiation and progression. However, the diverse characteristics and heterogeneity of cancer usually make confusion. Now, it is widely accepted that cancer evolves progressively from normal cells to malignant stages. During the multistep process, cancer cells acquired several hallmark capabilities which enable them to become tumorigenic and show all kinds of malignant phenotypes (Hanahan and Weinberg, 2000, 2011). Like other solid tumors, HCC is also characterized with those cancer hallmarks such as sustained cell proliferation, evading growth suppressors, resistant to cell death, invasion, metastasis, angiogenesis, and deregulated energy metabolism. The diverse malignant phenotypes of cancer cells usually associate with several genetic or epigenetic alterations of critical oncogenes or tumor suppressor genes. Thus, linking the hallmarks of HCC with genetic or epigenetic alterations will help to identify potential molecular mechanisms and find out novel targets for HCC treatment. Multiple cancer hallmarks and the underlying molecular alterations in the progression of HCC are summarized in Fig. 1.

\section{Sustained proliferation and replication}

The growth and proliferation of normal cells are strictly regulated to maintain a homeostasis of cell number and tissue architecture. However, in tumors, cell growth and proliferation are usually deregulated, and sustained cell proliferation is one of the most common traits of cancer cells. Cancer cells have several ways to obtain the ability to proliferate and replicate rapidly. One mechanism is that they can autocrine or paracrine growth factors which will further activate the mitogenic signaling pathways (Lemmon and Schlessinger, 2010). In HCC, cell growth factors such as IGF, FGF were reported to be overexpressed in a way of autocrine or paracrine and further promote cell growth and proliferation (Kim et al., 1998; Yoshiji et al., 2002). Growth factor receptors are usually overexpressed or mutated in tumor cells, which results in persistent activation of downstream mitogenic signals. In HCC, the overexpression of HGF receptor c-Met can activate the downstream Ras/Raf/MEK signaling pathway (Ueki et al., 1997). Overexpression of the Frizzled-7 receptor leads to the activation of Wnt/beta-caternin signaling pathway in HCC (Merle et al., 2004). In addition to direct overexpressing growth factors and receptors, cancer cells can also activate the mitogenic pathways through affecting the upstream and downstream signal transducers or disruption of the negative feed back loop. For example, the oncogenic signal transducer BRAF is frequently mutated and consistently activated in HCC (Colombino et al., 2012); loss 
of function mutation of PTEN, which is the negative feed back regulator of PI3K/AKT pathway, was also frequently observed in HCC patients (Yao et al., 1999).

\section{Evading growth suppressors and resistant to cell death}

In contrast to the proliferation stimulating signals, cells have also developed a growth inhibition system, which acts as a guardian of cell growth and proliferation. The guardian system is composed of series of growth and proliferation inhibitors, which are usually important tumor suppressor genes. The well-known tumor suppressor TP53 is at the center of the guardian system. Somatic mutation of TP53 is one of the most frequent genetic alterations in human cancer (Olivier et al., 2010). In HCC, TP53 was also found to be frequently mutated, and the common risk factors such as AFB1, HBV, and HCV are reported to cause TP53 mutation (Hussain et al., 2007; Ozturk, 1991). In addition to mutation of TP53 itself, the regulators of TP53 are usually found to be altered in cancer, such as MDM2. MDM2 ubiquitinates TP53 and promotes the proteasome-mediated degradation of TP53 (Kubbutat et al., 1997). Amplification and overexpression of MDM2 was frequently observed in HCC, and this might also account for the deregulated TP53 signaling pathway in HCC (Jablkowski et al., 2005). In addition to cell growth inhibition, cells can undergo apoptosis upon receiving extrinsic or intrinsic signals (Hengartner, 2000). The apoptotic signal is controlled by a group of counteracting proand anti-apoptotic proteins. The pro-apoptotic proteins such as Bax and Bak can enhance the permeability of mitochondria membranes and promote the release of cytochrome $\mathrm{c}$, which further activates the caspase cascade. The anti-apoptotic proteins such as $\mathrm{Bcl}-2$, Bcl-xl will counteract the pro-apoptotic proteins (Adams and Cory, 2007). Other regulatory proteins which interfere with the apoptotic signaling cascade, such as survivin, are also important antiapoptotic components (Adams and Cory, 2007). The overexpression of anti-apoptotic proteins such as Bcl-xl and survivin are frequently observed in HCC patients (Shiraki et al., 2000; Takehara et al., 2001).

\section{Invasion, metastasis, and angiogenesis}

Invasion and metastasis is one of the most common hallmarks of cancer, especially those with high grade malignancy. To gain invasive abilities, cancer cells usually undergo morphological changes termed "Epithelial-toMesechymal transition" (EMT). In epithelial tissues, cells are usually attached to each other or to the extracellular matrix (ECM) through adhesion molecules. However, in metastatic tumors, the adhesion molecules such as E-cadherin are usually down-regulated or mutated, and the loosened cell contact enables tumor cells to invade out from the primary niche (Cavallaro and Christofori, 2004). Conversely, adhesion molecules associated with cell migration such as $\mathrm{N}$-cadherin, which are usually expressed in migrating cells, will be up-regulated in the aggressive cancer cells. The morphology of the cell will also change from the epitheliallike phenotype to fibroblastic mesenchymal-like phenotype (Voulgari and Pintzas, 2009). In HCC, altered expression of E-cadherin was frequently observed and correlated with clinical pathological features (Wei et al., 2002). Loss of heterozygosity $(\mathrm{LOH})$ and $\mathrm{CpG}$ island hypermethylation have been proved to be the major mechanisms accounting for E-cadherin inactivation in HCC (Kanai et al., 1997). To date, several important transcriptional factors, such as Snail, Slug, Twist, and Zeb1/2, have been proved to be the key regulator of the EMT process. Overexpression of Snail and Twist has been closely correlated with HCC metastasis through inducing EMT (Lee et al., 2006; Sugimachi et al., 2003). In order to migrate from the original tissue, cancer cells need to degrade the barriers which hinder their movement, such as extracellular matrix. Matrix metalloproteinases (MMP) is a kind of secreted protease family, which can help digest the ECM (Stamenkovic, 2000). MMPs are synthesized in an inactive form, which could be activated after removing the pro-peptide domain (Pei et al., 2000). Overexpression and activation of MMPs are frequently observed in cancer cells, especially those with high metastatic ability (Rundhaug, 2003). Overexpression of MMPs, such as MMP-2 and MMP-9, are frequently observed in HCC patients and has been associated with cancer invasive potential (Arii et al., 1996; Giannelli et al., 2002).

Angiogenesis is another important feature of cancer. When tumor mass grows, the tumor cells need blood vesicles to provide enough nutrient and oxygen. Formation of tumor vessels can accelerate the proliferation, growth, and metastasis of cancer cells (Carmeliet and Jain, 2000). In the process of angiogenesis, tumor cells will secret several critical growth factors such as FGF, VEGF, which will activate the proliferation of endothelial cells or fibroblasts (Yancopoulos et al., 2000). VEGF has been proved to play a critical role in tumor angiogenesis including $\mathrm{HCC}$. Overexpression of VEGF was correlated with HCC angiogenesis and vascular formation (Mise et al., 1996). Monoclonal antibodies targeting VEGF or small molecules inhibiting VEGF receptors have already being used in HCC treatment (Finn and Zhu, 2009). In addition to VEGF, other proangiogenic factors including platelet-derived growth factor (PDGF), hepatoctye growth factor (HGF), basic fibroblast growth factor (bFGF), and angiopoietin-2 (Ang2) are also elevated in the HCC plasma and make a substantial contribution to HCC angiogenesis (Semela and Dufour, 2004; Zhu et al., 2011).

\section{Tumor-promoting microenvironment}

The initiation, growth, and metastasis of tumor not only depend on the malignant characteristics of cancer cells themselves, but also the tumor-promoting microenvironment (Joyce, 2005). Tumor grows in a complicated microenvironment, which is composed of stromal fibroblasts, endothelial 
cells, and infiltrating immune cells. These cells in the microenvironment can either secret growth factors to support tumor cell growth and angiogenesis, or produce pro-inflammatory cytokines and chemokines, which favors malignant transformation (Whiteside, 2008). For HCC, the tumor microenvironment might play a critical role in tumor initiation and progression. Etiological studies indicated that HCC mainly developed from liver cirrhosis, which is caused by chronic hepatitis virus infection, fatty liver disease, and alcohol abuse. The common trait during hepatocarcinogenesis is the sustained liver damage and regeneration, which leads to an inflammatory microenvironment in the liver. The inflammatory microenvironment supports the recruitment and activation of hepatic stellate cells and macrophages, which further produce components of the ECM, growth factors, and chemokines for angiogenesis and fibrosis (Hernandez-Gea et al., 2013).

There are several kinds of cells closely associated with HCC tumor microenvironment. Like other solid tumors, the most common cells observed in the tumor microenvironment are immune cells. In response to inflammatory signal, immune cells including T cells, B cells, macrophages, and dendritic cells will infiltrate into the tumor mass, and produce several kinds of cytokines, which either inhibit or promote tumor growth (Hernandez-Gea et al., 2013). The most common tumor-infiltrating lymphocyte is $\mathrm{CD}^{4+} \mathrm{T}$ helper cells. The cytokines secreted by Th cells could further be divided into two groups including Th1-like cytokines and Th2-like cytokines. A unique signature of increased Th1 cytokines (IL-1, IL-2, TNFa, etc.) but decreased Th2 cytokines (IL-4, IL-8, IL-10, etc.) was frequently observed in HCC tumor microenvironment and associated with poor prognosis of HCC patients (Ye et al., 2003). Tumor associated macrophage (TAM) is another important subset of infiltrated immune cells in the tumor microenvironment. High density of infiltrated TAMs usually associated with poor prognosis of HCC patients (Ding et al., 2009). TAMs can either secret tumor-promoting growth factor, cytokines, chemokines, etc. to facilitate tumor growth, or suppress the anti-tumor immunity in HCC tissues. The macrophages can also be divided into two subgroups like $T$ helper cells. TAMs resemble the M2 macrophages, which provide the formation of Th2 tumor microenvironment (Bingle et al., 2002).

\section{Cancer stem cell properties}

According to the cancer stem cell (CSC) model, cancer originates from a subset of stem like cells that have selfrenewal properties. Malignant cancer cells usually have similar properties as embryonic cells characterized with elevated stemness markers and maintained in a dedifferentiated status (Reya et al., 2001). Assessing the differentiation level of tumor is often conducted in the clinic, and the poorly-differentiated tumors are closely associated with patient prognosis. The histologically poorly-differentiated tumors usually show an embryonic-like gene expression signature (Ben-Porath et al., 2008). In HCC, certain cell populations have been identified as potential cancer stem cells. The "Oval cells" which give rise to hepatoblast cells and primitive bile duct cells during liver development are considered to be origins of liver cancer stem cells. Oval cells express cellular markers of both hepatocytes and bile duct, and have the potential to differentiate into both lineages. Therefore, oval cells are considered to be liver progenitor cells, which might be initiating cells in hepatocarcinogenesis (Mishra et al., 2009). A small group of cells known as "side population" (SP), which are able to pump out nucleus dye via ABCG2-transporters, are also considered to be potential liver cancer stem cells. SP cells have enhanced self-renewal ability in vitro and tumorigenic ability in vivo. Molecular characterization of SP cells indicated that several oncogenic signaling pathways associated with cancer self-renewal and differentiation, are activated in SP cells (Marquardt et al., 2011). In addition to oval cells and SP cells, several cell surface markers have been identified as cancer stem cell markers, including CD133, EpCam, CD90, CD24, etc. The isolated cancer cells using those markers all shown strong self-renewal properties and tumorigenic ability with only few cells injected in xenograph mouse model (Lee et al., 2011; Ma et al. 2007; Yamashita et al., 2009; Yang et al., 2008)

Several oncogenic signaling pathways have been proved to play important roles in regulating cancer stemness and differentiation. The well-known oncogene c-myc was reported to account for the embryonic stem cell like phenotype of cancer cells (Kim et al., 2010). Inactivation of the myc network can induce the differentiation of HCC cells (Shachaf et al., 2004). Wnt/ $\beta$-caternin is another important signaling pathway in regulating cancer stemness and differentiation. The secreted wnt will inhibit the cytoplasmic degradation of $\beta$-caternin, which further activates the $\beta$-caternin/TCF transcriptional machinery and promotes the transcription of several stemness markers such as Epcam, Ck19, and CD44, etc. (Fodde and Brabletz, 2007; Yamashita et al., 2007). In addition, other critical signaling pathways involved in regulating stem cell self-renewal and differentiation, such as Oct4, Nanog, Sox2, and Notch/Hedgehog have been reported to be important in maintaining the pluripotency of liver cancer progenitor cells and are frequently activated in HCC (Patil et al., 2006; Yuan et al., 2010).

\section{Energy metabolism switch}

Altered energy metabolism switch from oxidative phosphorylation to glycolysis, known as Warburg effect, has been widely accepted as an emerging hallmark of cancer. Early in the 1930s, oncologists and scientists have noticed the alteration of energy metabolism in malignant tumors. Glycolysis was preferentially used as the main program for energy metabolism in tumor cells even in the presence of oxygen (Cairns et al., 2011). In normal cells, ATP is mainly generated from the tricarboxylic acid (TCA) cycle, followed 
by oxidative phosphorylation in the mitochondria. Oxidative phosphorylation generates 36 molecules of ATP from one molecule of glucose. In contrast, the glycolysis only generates two molecules of ATP from one molecule of glucose (Kroemer and Pouyssegur, 2008). Although glycolysis is not efficient in generating energy, it can provide a large amount of nucleotides, fatty acids, membrane lipids to support the synthesis of macromolecules, which are required for rapid tumor growth. In compensation, cancer cells increased the glucose intake by up-regulating glucose transporters and enhancing the usage of glutamine. The Warburg-like metabolic switch found to be present in many rapidly dividing embryonic tissues further supported the hypothesis that glycolysis could generate diverse intermediates for biosynthetic programs that are important for active cell proliferation (Hsu and Sabatini, 2008).

The reduced dependence of cancer cells on oxidative phosphorylation is not only due to defects in the cellular components of TCA cycle, but also strictly regulated by series of oncogenes and tumor suppressor genes. Oncogenic activation of c-myc, Ras, Akt, and HIF, or inactivation of tumor suppressors such as TP53 can drive metabolism changes in cancer cells (Levine and Puzio-Kuter, 2010). Like other solid tumors, metabolic remodeling from mitochondrial oxidation to aerobic glycolysis is common in human HCC (Beyoglu et al., 2013). c-Myc was reported to induce mouse liver tumors with elevated glucose and glutamine catabolism (Yuneva et al., 2012). Hepatic mTORC2 can activate glycolysis and lipogenesis through phosphorylating AKT (Hagiwara et al., 2012). Multi-kinase inhibitor such as sorafenib, which targets those oncogenic signaling pathways, was reported to be able to reverse the metabolic reprogramming in HCC (Fiume et al., 2011).

\section{GENETIC ALTERATIONS IN HCC}

Genetic alteration is one of the most important mechanisms associated with HCC initiation and progression. Genetic changes could be observed as early as in the pre-neoplastic lesions of cirrhotic liver, and it is thought to be the initiating events in hepatocarcinogenesis. The irreversible genetic abnormalities accumulate in hepatocytes, which further cause disrupted gene expression, and finally lead to malignant transformation. Genetic alterations could be divided into several types, including large chromosomal amplification, translocation, deletion, small fraction loss, and single nucleotide variation. The genetic changes at all levels usually result in the activation or loss-of-function of certain important oncogenes or tumor suppressor genes, which govern cell growth and proliferation.

\section{Chromosomal instability}

Chromosomal instability is the most common genetic changes in HCC. It could be induced by either error during mitosis or disruption in DNA replication and repair. The chromosome abnormalities could be observed as the gain and loss of whole chromosome arms, or just amplification and deletion of small chromosomal fragments. According to the comparative genomic hybridization $(\mathrm{CGH})$ data, chromosome $1 \mathrm{q}$ and $8 q$ are frequently amplified, while chromosome $1 p, 4 q$, $6 q, 9 p, 16 p, 16 q$, and $17 p$ are frequently lost in HCC (Guan et al., 2000). The observation of chromosomal alterations in preneoplastic liver tissues indicated that chromosome instability may occur in the early stage of $\mathrm{HCC}$, and accumulates during tumor progression (Kondo et al., 2000). Thus chromosome instability may activate certain cancer driver genes during hepatocarcinogenesis.

Amplification of chromosome $1 \mathrm{q}$ is one of the most frequently observed chromosome abnormalities in HCC. The minimal region of 1q21 was found to be amplified in more than $50 \%$ of $\mathrm{HCC}$ patients. A well characterized oncogene CHD1L is localized in that region (Ma et al., 2008). CHD1L was found to have several oncogenic roles such as inhibiting cell apoptosis, regulating cell mitosis, and promoting cell epithelial-to-mesenchymal (EMT) transition during hepatocarcinogenesis (Chan et al., 2012; Chen et al., 2010; Chen et al., 2009a). In a transgenic mice model, CHD1L could induce spontaneous liver tumors formation (Chen et al., 2009b). In addition, CHD1L could regulate p53 stability, potentially via interacting with SCYLIBP1, which modulates the pirh2-mediated ubiquitin degradation of p53 (Hu et al., 2012). Adenovirus-mediated silencing of CHD1L could inhibit HCC tumorigenesis in xenograft mouse model further suggested CHD1L as a potential therapeutic target in $\mathrm{HCC}$ treatment (Chen et al., 2011). In addition to chromosome $1 q 21$, a recent study indicated that a novel potential oncogene Maelstrom (MAEL) at 1q24, could induce EMT and enhance stemness properties of HCC cells (Liu et al., 2013). Chromosome $8 q$ is another highly amplified chromosome arm in $\mathrm{HCC}$, especially at the 8q24 region (Wang et al., 2002). Well-known oncogenes including c-Myc and PTK2 are located at this region, and have been characterized for their oncogenic effects on HCC development (Okamoto et al., 2003; Santoni-Rugiu et al., 1998). In addition to 8q24, the chromosomal region proximal to the centromere is also frequently amplified in HCC (Parada et al., 1998). A serine/ threonine kinase SGK3, which shares great similarity with AKT, was found to be frequently amplified and confer AKTindependent oncogenic roles in HCC (Liu et al., 2012).

Chromosome segmental loss is also frequently observed in HCC. The minimal region of 1 p35-36 was found to be deleted in more than $50 \%$ HCC patients. Several tumor suppressors such as 14-3-3 $\sigma$ and $\mathrm{Rb}$-interacting zinc finger 1 (RIZ1) were located in this region (Iwata et al., 2000). Loss of the short arm of chromosome 8 has been recurrently observed in HCC. A minimal region of $8 p 21-22$ was found to be frequently deleted in HCC. Deleted in liver cancer 1 (DLC-1), which is a homolog of the rat RhoGAP gene, is located in that region (Yuan et al., 1998). DLC-1 is frequently deleted in HCC tissues due to allele 
Table 1. Aberration of chromosome and candidate target genes reported in HCC.

\begin{tabular}{|c|c|c|c|}
\hline Chromosome & Type of aberration & $\begin{array}{l}\text { Frequent aberration region and candidate target } \\
\text { genes (Location) }\end{array}$ & References \\
\hline $1 q$ & Gain & $\begin{array}{l}\text { CKS1B (1q21.2), CHD1L (1q21.1), JTB (1q21), } \\
\text { MDM4 (1q32.1) }\end{array}$ & Chen et al., 2010; Kim et al., 2008 \\
\hline $1 p$ & Loss & $\begin{array}{l}\text { p18 (1p32), 14-3-3o (1p35), p73 (1p36.3), RIZ } \\
\quad(1 \mathrm{p} 36.13-\mathrm{p} 36.23)\end{array}$ & $\begin{array}{l}\text { Nishimura et al., 2005; Iwata et al., } \\
\text { 2000; Fang et al., } 2000\end{array}$ \\
\hline $3 q$ & Gain & Gankyrin (3q28) & Higashitsuji et al., 2000 \\
\hline $3 p$ & $\begin{array}{l}\text { LOH, CpG } \\
\text { methylation }\end{array}$ & $\begin{array}{l}\text { RASSF1A (3p21.3), CTNNB1 (3p21), TGF-1ßR11 } \\
\text { (3q22) }\end{array}$ & $\begin{array}{l}\text { Zhang et al., 2002; Miyoshi et al., } \\
1998\end{array}$ \\
\hline $4 q$ & $\mathrm{LOH}$ & & Zondervan et al., 2000 \\
\hline $6 p$ & Gain & & Chochi et al., 2009 \\
\hline $6 q$ & $\mathrm{LOH}$ & M6P/IGF2R (6q26-q27) & Oka et al., 2002 \\
\hline $8 q$ & Gain & $\begin{array}{l}\text { c-Myc (8q24.21), PTK2 (8q24.3), EIF3S3 (8q23.3), } \\
\text { SGK3 (8q13.1) }\end{array}$ & $\begin{array}{l}\text { Santoni-Rugiu et al., 1998; Okamoto } \\
\text { et al., 2003; Liu et al., } 2012\end{array}$ \\
\hline $8 p$ & $\begin{array}{l}\mathrm{LOH}, \mathrm{CpG} \\
\text { methylation }\end{array}$ & DLC-1 (8p21.3-22), LPTS (8p23), CSMD1 (8p23.2) & Yuan et al., 1998 \\
\hline $9 p$ & $\begin{array}{l}\mathrm{LOH}, \mathrm{CpG} \\
\text { methylation }\end{array}$ & $C D K N 2 A(9 \mathrm{p} 21), C D K N 2 B(9 \mathrm{q} 21)$ & Wang et al., 2000 \\
\hline $10 q$ & $\mathrm{LOH}$ & PTENIMMAC1 (10q23.3) & Fujiwara et al., 2000 \\
\hline $11 q$ & Gain & cyclinD1 (11q13) & Nishida et al., 1994 \\
\hline $11 p$ & $\begin{array}{l}\text { LOH, CpG } \\
\text { methylation }\end{array}$ & KAl1 (11p11.2), IGF-2 (11p15), TSLC1 (11q23.2) & Tsujiuchi et al., 2007 \\
\hline $13 q$ & $\mathrm{LOH}$ & $\begin{array}{l}R b 1(13 q 14.2), B R C A 2(13 q 12.3), \operatorname{Tg} 737(13 q 12.1) \\
\quad T F D P 1(13 q 34), C U L 4 A(13 q 34), C D C 1 \text { (13q34) }\end{array}$ & Kuroki et al., 1995; Yasui et al., 2002 \\
\hline $16 q$ & $\begin{array}{l}\mathrm{LOH}, \mathrm{CpG} \\
\text { methylation }\end{array}$ & $C D H 1(16 q 22.1)$ & Wang et al., 2000 \\
\hline $16 \mathrm{p}$ & CpG methylation & Axin1 (16p13.3), SOCS-1 (16p13.3) & Li et al., 2013c; Ko et al., 2008 \\
\hline $17 p$ & $\mathrm{LOH}$ & p53 (17p13.1), HIC-1 (17p13.3), HCCS1 (17p13.3) & $\begin{array}{l}\text { Nishida et al., 1993; Kanai et al., } \\
\text { 1999; Zhao et al., } 2001\end{array}$ \\
\hline
\end{tabular}

loss and promoter hypermethylation (Wong et al., 2003). Restore DLC-1 expression in hepatoma cells could induce cell apoptosis, and inhibit tumor growth (Zhou et al., 2004). Chromosome $16 \mathrm{q}$ is another region with frequent deletion in HCC. Cell adhesion molecule E-cadeherin (CDH1), which inhibits cell proliferation and metastasis, is located on $16 q 22$ (Kanai et al., 1997). Another tumor suppressor gene Tyrosine aminotransferase (TAT), which might contribute to the pathogenesis of HCC, is also located on 16q22 (Fu et al., 2010). Recently, a significant allele-specific imbalance was identified in the $16 q 23$ region in a cohort of $\mathrm{HCC}$ patient due to $\mathrm{LOH}$. The affected gene Oxidative Stress-Induced Growth Inhibitor 1 (OSGIN1) can directly induce cell apoptosis in HCC cells and contributes significantly to the progression of HCC (Liu et al., 2014). The well-known tumor suppressor TP53 is mapped to $17 p 13.1$, which is also a recurrently lost region in HCC. The $17 \mathrm{p} 13$ region was characterized with DNA hypermethylation, and loss of $17 \mathrm{p} 13.1$ was closely associated with TP53 mutation (Nishida et al., 1993). Summary of chromosome alterations and candidate target genes reported in $\mathrm{HCC}$ was listed in Table 1.

\section{Genomic mutations}

In addition to large chromosomal alterations, genomic mutation is another important genetic alteration which contributes to tumor initiation and progression. Genomic mutations could be divided into germline mutations and somatic mutations. A germline mutation is usually inherited, and exists in all cell types of a body. Germline mutations are rare, and usually account for cancer risk in certain families. In contrast, somatic mutations usually exist in tumor tissues or preneuplastic tissues, and accumulate during cancer progression. Somatic mutations are more common, and might account for malignant transformation of sporadic tumors. Missense genomic mutations at the open reading frame can either lead to loss-of-function of tumor suppressors or gainof-function of oncogenes. In addition, mutations at the noncoding region of the genome can also affect cancer risk and progression, for they may change the transcription, translation, or stability of the gene product.

With the development of the next-generation high throughput deep sequencing technology, scientists now are 
able to identify somatic mutation patterns in a certain tumor tissue, like HCC. Recently, two groups have sequenced the whole genome of several HCC tumor tissues and their paired non-tumor tissues (Fujimoto et al., 2012; Guichard et al., 2012). Recurrent somatic mutations were enriched in several signaling pathways including wnt/ $\beta$-catenin, p53/cell cycle control, chromatin remodeling, PI3K/Ras signaling, and oxidative and endoplasmic reticulum stress. The wnt signaling pathway was found to be the most frequently altered in HCC. Activating mutation in CTNNB1 was found in $32.8 \%$ of HCC patients. While the inactivating mutations of AXIN1 and APC was found in $15.2 \%$ and $1.6 \%$ of $\mathrm{HCC}$ patients, respectively. The second most altered pathway in $\mathrm{HCC}$ is the p53 signaling pathway. Inactivation mutation of p53 was present in $20.8 \%$ of HCC patients and mutation in CDKN2A was identified in $8 \%$ of HCC patients. In addition to other traditional signaling pathways, which are frequently mutated in cancer, several recent studies reported that the components of the chromosome remodeling complex are frequently mutated in many cancer types including $\mathrm{HCC}$. The mutation of the SWI/SNF chromatin remodeling complex component ARID1A was detected in more than $20 \%$ of $\mathrm{HCC}$ patients. These indicated that the chromatin remodeling complex might play important roles in cancer initiation and progression.

\section{Cancer susceptibility genes}

It is widely accepted that genetic polymorphisms at cancer susceptibility genes can affect the cancer risk of certain population. Unlike genetic mutations, which directly cause loss-of-function or gain-of-function of gene products, and usually affect important oncogenes or tumor suppressor genes involved in critical signaling pathways, nucleotide changes in cancer susceptibility alleles might not directly cause dramatic functional changes of a protein. Instead, cancer susceptible genetic variations might slightly affect the function of a protein, for example the efficiency of an enzyme, thus confer an increased cancer risk for certain population. A wide range of genes are associated with cancer risk, including carcinogen metabolism genes, antitumor immune response genes, and genes associated with cellular response to stress (Antoniou et al., 2010).

Genome-wide association study (GWAS) is emerging as a powerful tool to identify cancer susceptibility alleles in tumorigenesis. GWAS examines common genetic variants in different individuals and identifies variants associated with certain disease. In contrast to mendelian linkage analysis, which aims to identify highly penetrant tumorigenic mutations, GWAS is powerful in identifying less penetrant tumor susceptibility alleles, which are more common and might be important in cancer initiation and progression. Several GWASs have been performed to identify susceptibility alleles associated with HCC. Intronic SNP (rs17401966) in KIF1B on chromosome 1 p36.22 has been linked to HBV- associated HCC (Zhang et al., 2010). Chromosome loci 6p21.32 and 21q21.3 have also been associated with HCC in chronic HBV carriers ( $\mathrm{Li}$ et al., 2012). A recent study indicated that genetic variations in STAT4 and HLA-DQ genes may confer risk of HBV-related HCC (Jiang et al., 2013). SNP (rs2596542) in the $5^{\prime}$ flanking region of MICA on 6 21.33 has been linked to HCV-associated HCC (Kumar et al., 2011).

\section{MicroRNAs (miRNAs)}

MicroRNA, a class of non-coding RNAs, has been identified as important regulators of gene expression at post transcriptional levels. Emerging evidences indicated that miRNAs are associated with the development and progression of HCC. In recent years, intensive investigations have been conducted to find out the abnormally expressed miRNAs and their roles in HCC development and progression. Some miRNAs can regulate the proliferation pathways via modulating cyclins or cyclin-dependent kinases, such as miR-122a and miR-221 (Gramantieri et al., 2007). Some miRNAs can help HCC cells to escape from apoptosis by targeting pro-apoptotic protein. For example, Bmf, a proapoptotic protein, is a target of miR221 (Gramantieri et al., 2009). On the contrary, other miRNAs can promote HCC apoptosis. For example, the anti-apoptotic proteins $\mathrm{Bcl}-2$ and $\mathrm{Mcl}-1$ are two direct targets of miR-29 (Xiong et al., 2010). As two of the most critical hallmarks of $\mathrm{HCC}$, invasion and metastasis are also regulated by miRNAs. On the one hand, the pro-metastatic miRNAs can promote cell migration and spreading in HCC. For example, miR-106b can promote $\mathrm{HCC}$ cell migration and invasion by activating epithelial-mesenchymal transition (EMT) process (Yau et al., 2013). On the other hand, several miRNAs such as let-7g, miR-139, and miR-195 can suppress metastasis and progression of HCC (Ji et al., 2010; Wang et al., 2013b). Additionally, some miRNAs have been reported to enhance the ability of self-renewal and tumorigenicity of HCC. MiR-130b can regulate CD133(+) liver cancer stem cells via silencing TP53INP1 (Ma et al., 2010). Inhibition of miR-181 can result in a reduction in $\operatorname{EpCAM}(+) \mathrm{HCC}$ cell quantity. Exogenous miR181 expression in HCC cells led to an enrichment of EpCAM (+) HCC cells and promote tumor initiating ability (Ji et al., 2009). Summary of the abnormally expressed miRNAs and their functions are listed in Table 2.

\section{RNA editing}

The RNA transcripts are usually faithfully transcribed from the genome without sequential changes after RNA processing. However RNA editing is a molecular process which could result in nucleotide changes at specific sites of the RNA transcripts. Thus, RNA editing could add great diversity to the posttranscriptional regulation of gene expression (Gott and Emeson, 2000). RNA editing can modify the transcribed RNA sequences via nucleotide insertion, deletion, and substitution. The most common type of RNA editing in human is 
Table 2. MiRNAs aberrantly expressed and validated target genes in hepatocellular carcinoma.

\begin{tabular}{|c|c|c|c|c|}
\hline miRNA & Expression & Gene targets & Function & References \\
\hline $\begin{array}{l}\text { miR- } \\
17-5 p\end{array}$ & Up & p38, MAPK pathway, E2F-1, c-MYC & $\begin{array}{l}\text { Promote tumor growth and } \\
\text { metastasis. }\end{array}$ & $\begin{array}{l}\text { Yang et al., 2010; El Tayebi } \\
\text { et al., } 2013\end{array}$ \\
\hline $\begin{array}{l}\mathrm{miR}- \\
18 \mathrm{a}\end{array}$ & Up & $\mathrm{ERa}$ & Promote proliferation. & Liu et al., 2009 \\
\hline $\begin{array}{l}\mathrm{miR}- \\
18 \mathrm{~b}\end{array}$ & Up & TNRC6B & $\begin{array}{l}\text { Promote cell proliferation and } \\
\text { loss of cell adhesion. }\end{array}$ & Murakami et al., 2013 \\
\hline $\operatorname{miR}-21$ & Up & PTEN, RECK, PDCD4 & $\begin{array}{l}\text { Inhibit apoptosis, promote cell } \\
\text { migration and invasion. }\end{array}$ & $\begin{array}{l}\text { Meng et al., 2007; Zhou } \\
\text { et al., } 2013\end{array}$ \\
\hline $\begin{array}{l}\mathrm{miR}- \\
106 \mathrm{~b}\end{array}$ & Up & E2F1, RhoGTPases, RhoA, RhoC & $\begin{array}{l}\text { Promote cell migration and } \\
\text { stress fiber formation. }\end{array}$ & Yau et al., 2013 \\
\hline $\begin{array}{l}\text { miR- } \\
130 \mathrm{~b}\end{array}$ & Up & TP53INP1 & $\begin{array}{l}\text { Promote CD133(+) liver } \\
\text { cancer stem cell growth and } \\
\text { self-renewal. }\end{array}$ & Ma et al., 2010 \\
\hline $\begin{array}{l}\mathrm{miR}- \\
143\end{array}$ & Up & FNDC3B & Promote tumor metastasis. & Zhang et al., 2009 \\
\hline $\begin{array}{l}\mathrm{miR}- \\
151\end{array}$ & Up & RhoGDIA, FAK, & $\begin{array}{l}\text { Stimulate tumor invasion and } \\
\text { metastasis. }\end{array}$ & $\begin{array}{l}\text { Ding et al., 2010; Luedde, } \\
2010\end{array}$ \\
\hline $\begin{array}{l}\text { miR- } \\
181 b\end{array}$ & Up & TIMP3 & Promote tumor metastasis. & Wang et al., 2010a \\
\hline $\begin{array}{l}\mathrm{miR}- \\
181\end{array}$ & Up & CDX2, GATA6,NLK & $\begin{array}{l}\text { Promote EpCAM(+) liver } \\
\text { cancer stem cell growth } \\
\text { and self-renewal. }\end{array}$ & Ji et al., 2009 \\
\hline $\begin{array}{l}\text { miR- } \\
185\end{array}$ & Up & KCNN3 & $\begin{array}{l}\text { Association with HCC venous } \\
\text { metastasis. }\end{array}$ & Budhu et al., 2008 \\
\hline $\begin{array}{l}\text { miR- } \\
210\end{array}$ & Up & VMP1 & $\begin{array}{l}\text { Promote hypoxia-induced } \\
\text { HCC cell metastasis. }\end{array}$ & Ying et al., 2011 \\
\hline $\begin{array}{l}\text { miR- } \\
221 / \\
222\end{array}$ & Up & $\begin{array}{l}\text { CDKN1B/p27,CDKN1C/p57, DDIT4, } \\
\text { PTEN, Bmf, TIMP3, PPP2R2A }\end{array}$ & $\begin{array}{l}\text { Inhibit apoptosis, promote } \\
\text { tumor growth and } \\
\text { metastasis. }\end{array}$ & $\begin{array}{l}\text { Fornari et al., 2008; } \\
\text { Gramantieri et al., } 2009\end{array}$ \\
\hline $\begin{array}{l}\mathrm{miR}- \\
224\end{array}$ & Up & $\begin{array}{l}\text { API-5, CDC42, CDH1, PAK2, BCL-2, } \\
\text { MAPK1, PPP2R1B. }\end{array}$ & $\begin{array}{l}\text { Promote cell proliferation, } \\
\text { migration, invasion, and } \\
\text { inhibit cell apoptosis. }\end{array}$ & $\begin{array}{l}\text { Wang et al., 2008; Zhang } \\
\text { et al., } 2013\end{array}$ \\
\hline miR-1 & Down & FoxP1, MET, HDAC4. & $\begin{array}{l}\text { Inhibition of cell growth and } \\
\text { reduced replication potential. }\end{array}$ & Datta et al., 2008 \\
\hline let-7 & Down & c-Myc, p16, Bcl-xI, COLIA2. & $\begin{array}{l}\text { Inhibition of cell growth and } \\
\text { proliferation. }\end{array}$ & $\begin{array}{l}\text { Wang et al., 2010b; Ji et al., } \\
2010\end{array}$ \\
\hline $\begin{array}{l}\text { miR- } \\
26 a\end{array}$ & Down & $\begin{array}{l}\text { Cyclin D2, Cyclin E2,Cyclin E1, } \\
\text { CDK6, IL-6 }\end{array}$ & $\begin{array}{l}\text { Inhibit tumor growth, } \\
\text { metastasis, and invasion. }\end{array}$ & Yang et al., 2013 \\
\hline $\operatorname{miR}-29$ & Down & MEG3, Bcl-2, Mcl-1 & $\begin{array}{l}\text { Promotion of apoptosis and } \\
\text { inhibition of tumor growth }\end{array}$ & Xiong et al., 2010 \\
\hline $\begin{array}{l}\mathrm{miR}- \\
34 \mathrm{a}\end{array}$ & Down & c-Met & $\begin{array}{l}\text { Inhibition of cell growth, } \\
\text { migration, and invasion. }\end{array}$ & Li et al., 2009 \\
\hline $\begin{array}{l}\mathrm{miR}- \\
122\end{array}$ & Down & $\begin{array}{l}\text { CyclinG1, ADAM10, SRF, IGF1R, } \\
\text { PTTG1, PBF,CUTL1, NDRG3, } \\
\text { MDR-1 }\end{array}$ & $\begin{array}{l}\text { Inhibit viral replication and cell } \\
\text { proliferation. }\end{array}$ & $\begin{array}{l}\text { Song et al., 2012; Li et al., } \\
\text { 2013a; Xu et al., 2010; } \\
\text { Gramantieri et al., } 2007\end{array}$ \\
\hline $\begin{array}{l}\mathrm{miR}- \\
124\end{array}$ & Down & ROCK2, EZH2, PIK3CA & $\begin{array}{l}\text { Inhibit tumor growth, invasion, } \\
\text { and metastatic potential of } \\
\text { HCC. }\end{array}$ & $\begin{array}{l}\text { Zheng et al., 2012; Lang and } \\
\text { Ling, } 2012\end{array}$ \\
\hline $\begin{array}{l}\text { miR- } \\
126\end{array}$ & Down & ROCK2, c-Fos & $\begin{array}{l}\text { Inhibit cell invasion and } \\
\text { migration. }\end{array}$ & Wong et al., 2011 \\
\hline
\end{tabular}


Table 2 continued

\begin{tabular}{|c|c|c|c|c|}
\hline miRNA & Expression & Gene targets & Function & References \\
\hline $\begin{array}{l}\mathrm{miR}- \\
145\end{array}$ & Down & $\begin{array}{l}\text { OCT4, IRS1, IRS2, IGF signaling, } \\
\text { HDAC2. }\end{array}$ & $\begin{array}{l}\text { Inhibit cell proliferation, } \\
\text { migration, and invasion. }\end{array}$ & $\begin{array}{l}\text { Wang et al., 2013a; Law } \\
\text { et al., 2012; Noh et al., } \\
2013\end{array}$ \\
\hline $\begin{array}{l}\text { miR- } \\
148 a\end{array}$ & Down & $\begin{array}{l}\text { HPIP, AKT/ERK/FOXO4/ATF5 } \\
\text { pathway }\end{array}$ & Inhibit tumorigenesis. & Xu et al., 2013 \\
\hline $\begin{array}{l}\mathrm{miR}- \\
195\end{array}$ & Down & $\begin{array}{l}\text { cyclin D1, CDK6, E2F3, LATS2, } \\
\text { VEGF, VAV2, CDC42, IKKa and } \\
\text { TAB3, TNF- } \alpha \text { /NF-KB pathway }\end{array}$ & $\begin{array}{l}\text { Inhibit G1/S transition, } \\
\text { angiogenesis, and } \\
\text { metastasis, promote } \\
\text { apoptosis. }\end{array}$ & $\begin{array}{l}\text { Xu et al., 2009; Wang et al., } \\
\text { 2013b; Ding et al., } 2013\end{array}$ \\
\hline $\begin{array}{l}\text { miR- } \\
\text { 199a- } \\
3 p\end{array}$ & Down & mTOR, c-Met, CD44 & $\begin{array}{l}\text { Inhibit cell growth and } \\
\text { metastasis }\end{array}$ & $\begin{array}{l}\text { Fornari et al., 2010; Henry } \\
\text { et al., } 2010\end{array}$ \\
\hline $\begin{array}{l}\mathrm{miR}- \\
214\end{array}$ & Down & $\begin{array}{l}\text { XBP-1, HDGF, EZH2, CTNNB1, } \\
\beta \text {-catenin signaling pathway }\end{array}$ & $\begin{array}{l}\text { Inhibit cell proliferation, } \\
\text { promote cell apoptosis, and } \\
\text { suppress tumor vascularity. }\end{array}$ & $\begin{array}{l}\text { Shih et al., 2012; Xia et al., } \\
2012\end{array}$ \\
\hline $\begin{array}{l}\mathrm{miR}- \\
223\end{array}$ & Down & stathmin1 & Inhibit cell proliferation & Wong et al., 2008 \\
\hline $\begin{array}{l}\mathrm{miR}- \\
375\end{array}$ & Down & YAP, AEG-1, ATG7 & Inhibit tumorigenesis & $\begin{array}{l}\text { Liu et al., 2010; He et al., } \\
\text { 2012; Chang et al., } 2012\end{array}$ \\
\hline
\end{tabular}

the adenosine to inosine (A-to-l editing), which is mediated by theadenosine deaminase acting on dsRNA (ADAR) family of enzymes. The A-to-l editing can affect various types of RNA molecules including mRNAs, microRNAs, viral RNAs, etc. (Athanasiadis et al., 2004). RNA editing at the coding regions of the transcripts may lead to non-synonymous amino acid changes in the gene products, which might affect the biological functions of the proteins. Recent studies have linked A-to-I RNA editing to hepatocarcinogenesis. Through next-generation RNA sequencing technology, an A-to-I editing event within the AZIN1 transcript was identified in the tumor tissues from $\mathrm{HCC}$ patients. Hyper-editing of AZIN1 transcripts in the tumor cells resulted in a recording of AZIN1 protein from Serine to Glysine at coden 367. The edited AZIN1 showed strong oncogenic phenotypes on HCC cell lines and mouse models, compared with the wild type form. The frequency of RNA editing in the tumor tissues also significantly associated with the prognosis of HCC patients (Chen et al., 2013). The disrupted RNA editing was found to be mediated by differential expression of ADARs in HCC (Chan et al., 2013). Further characterization of the RNA editing events in $\mathrm{HCC}$ might help elucidate the pathogenesis of this disease (Li et al., 2013b).

\section{EPIGENETIC ALTERATIONS IN HCC}

Genetic alterations are irreversible changes that affect the DNA sequence of the genome. In contrast, epigenetic regulations do not change the sequence of the genome but affect the chromatin structure and gene transcription. Epigenetic regulations affect gene products at multiple levels, including both transcriptional level and post-transcriptional regulation, which added great diversity to the gene regulation network. DNA methylation, histone modification, and recently emerging IncRNA, are major forms of epigenetic regulations. Alterations at cellular machineries governing those processes are frequently observed in cancer cells including HCC. The epigenetic alterations usually result in the activation of oncogenes or inactivation of tumor suppressor genes, which further contribute to malignant cancer hallmarks. Increasing evidences suggested that epigenetic alterations are evolving as an important mechanism in cancer initiation and progression (Momparler, 2003).

\section{DNA methylation}

In a normal cell, DNA methylation and demethylation is an important mechanism in regulating gene expression and chromatin structure. DNA methylase (DNMT) catalyze the methylation of cytosine at $\mathrm{CpG}$ islands at the promoter region of a gene. However, in tumor cells, the promoter methylation pattern is usually changed. Aberrant DNA methylation at the promoter region is an important mechanism of tumor suppressor gene inactivation. The hypermethylated $\mathrm{CpG}$ islands at the promoter region will prevent the binding of RNA polymerase and transcriptional factors, thus inhibit the transcription of the target genes. In addition, the hypermethylated protein will recruit $\mathrm{m}^{5} \mathrm{CpG}$-binding domain (MBD) containing proteins, which will be an obstacle for the binding of transcriptional factors to the promoters, thus inhibit gene transcription (Hendrich and Bird, 1998). 
In HCC, CpG island hypermethylation is frequently observed at the promoter region of important tumor suppressor genes. Suppressor of cytokine signaling (SOCS-1), which regulates the JAK/STAT signaling pathway, was found to be silenced in more than $60 \%$ of $\mathrm{HCC}$ patients due to promoter hypermethylation (Yoshikawa et al., 2001). The well-known tumor suppressor APC and E-cadeherin were also hypermethylated in $53 \%$ and $49 \%$ of HCC patients, respectively (Yang et al., 2003). Methylation profiling of multistep HCC tumors revealed that the number of genes methylated showed stepwise increase with the progression of cancer stage. The observation of tumor suppressor gene hypermethylation in the para-tumor liver tissues and cirrhotic livers indicated that aberrant promoter methylation occurs in the early stage of hepatocarcinogenesis and increased progressively during cancer progression (Lee et al., 2003). In addition, genome-wide DNA methylation analysis revealed that epigenetic silencing of multiple tumor suppresors in HCC could result in the activation of several oncogenic signaling pathways including Ras, JAK/STAT, and Wnt/ $\beta$ catenin (Calvisi et al., 2007).

There are several proposed hypotheses for the aberrant DNA methylation in cancer. One possible mechanism is the aberrant expression of DNMT1. As part of the DNA replication complex, DNMT1 transfer the methyl to the DNA immediately after DNA replication. In cancer cells, DNMT1 is usually abnormally expressed, and this will commit methylation errors during DNA replication (Vertino et al., 2002). Significant increase of DNMT1 was observed in HCC patients (Saito et al., 2003). In addition to DNMT1, which mainly accounts for the maintenance of methylation pattern of the genome, other DNMT family members such as DNMT3A and DNMT3B can directly add methyl groups to unmethylated DNA. DNMT3A and DNMT3B are responsible for novel methylation pattern formation in the genome (Okano et al., 1999). DNMT3A and DNMT3B were reported to be associated with hypermethylation of several important tumor suppressor genes, such as CDKN2A, CDKN2B, $\mathrm{CDH} 1$, and Rb1 (Mizuno et al., 2001). The expression of DNMT3A and DNMT3B are both significantly overexpressed in $\mathrm{HCC}$ compared with the non-cancerous liver tissues (Oh et al., 2007).

\section{Histone modification and chromatin remodeling}

Chromatin is the fundamental structure of the genome, which is constituted by nucleosome particles. The chromatin structure is important to gene transcription. In active transcription sites, the chromatin will be loosened, so that the DNA can be exposed to transcriptional factors for transcription initiation. This open chromatin structure is termed "euchromatin". In contrary, some of the chromatin structure is heavily condensed and the transcriptions of those genes within those regions are inhibited. The condensed chromatin structure is termed "heterochromatin". Thus, chromatin structure is of critical importance in regulating gene expression in a temporal and spatial dependent manner (Wang et al., 2007a).

Histone modification is playing a central role in chromatin structure regulation. Covalent modification of histones with methylation or acetylation will result in the chromatin structural change and could be used as markers for chromatin structure. There are two histone modification markers which represent an active transcription. Trimethylation of $\mathrm{H} 3$ lysine $4(\mathrm{H} 3 \mathrm{~K} 4 \mathrm{Me} 3)$ is often observed at the promoter region of actively transcribed genes. Trimethylation of $\mathrm{H} 3$ lysine 36 (H3K36Me3) is also closely associated with active transcription. In contrary, trimethylation of $\mathrm{H} 3$ lysine 27 (H3K27Me3) and trimethylation of $\mathrm{H} 3$ lysine 9 (H3K9Me3) are associated with repressed transcription (Kouzarides, 2007). It is recognized that histone modification is catalyzed by several enzymes which modulate the histone markers. The histone modifiers include histone methyltransferases (HMT), histone acetylatransferase (HAT), and histone deacertylase (HDAC), etc. Abnormal expression of those histone modifiers which further drives epigenetic alterations are frequently observed in cancer cells. In HCC, overexpression of $E Z H 2$, which is the histone methyltransferase for $\mathrm{H} 3 \mathrm{~K} 27 \mathrm{Me}$, has been proven to contribute to the malignant transformation and poor prognosis of HCC (Chen et al., 2007; Sudo et al., 2005). The P300/CBP-associated factor (PCAF), which is a well-known HAT, was expressed at low level in HCC, and has been proven to inhibit HCC tumorigenesis both in vitro and in vivo (Zheng et al., 2013). HDAC inhibitors have been suggested to specifically induce apoptosis in hepatoma cells but not in primary hepatocytes. And these results greatly supported the potential application of HDAC inhibitors in clinical treatment of HCC patients (Armeanu et al., 2005; Pathil et al., 2006).

In addition to histone modifiers, the ATP-dependent chromatin remodeling complex, which utilize ATP to mobilize nucleosomes along DNA, are also closely involved in tumorigenesis. The ATP-dependent chromatin remodeling family could be further divided into four subfamilies including: the SWI/SNF (Switching defective/, sucrose non-fermenting) family, the ISWI family (imitation SWI), the NuRD/CHD (Nucleosome remodeling and deacetylation/Chromodomain helicase, DNA binding) family, and the INO80 (inositol requiring 80 ) family (Wang et al., 2007). Whole-genome sequencing has identified recurrent somatic mutations in genes associated chromatin remodeling complex, including ARID1A, ARID2, and SMARCA4 (Guichard et al., 2012; Li et al., 2011). The frequently observed inactivating mutations indicated the important roles of chromatin remodeling complex in HCC development. The ATPase and putative DNA helicase RuvB-like 2 (RUVBL2) was found to be overexpressed in HCC and has contributed to the malignant transformation (Rousseau et al., 2007). Copy number loss or down-regulation of SWI/SNF chromatin remodelling subunitBRG1 and BRM were also frequently observed in HCC 


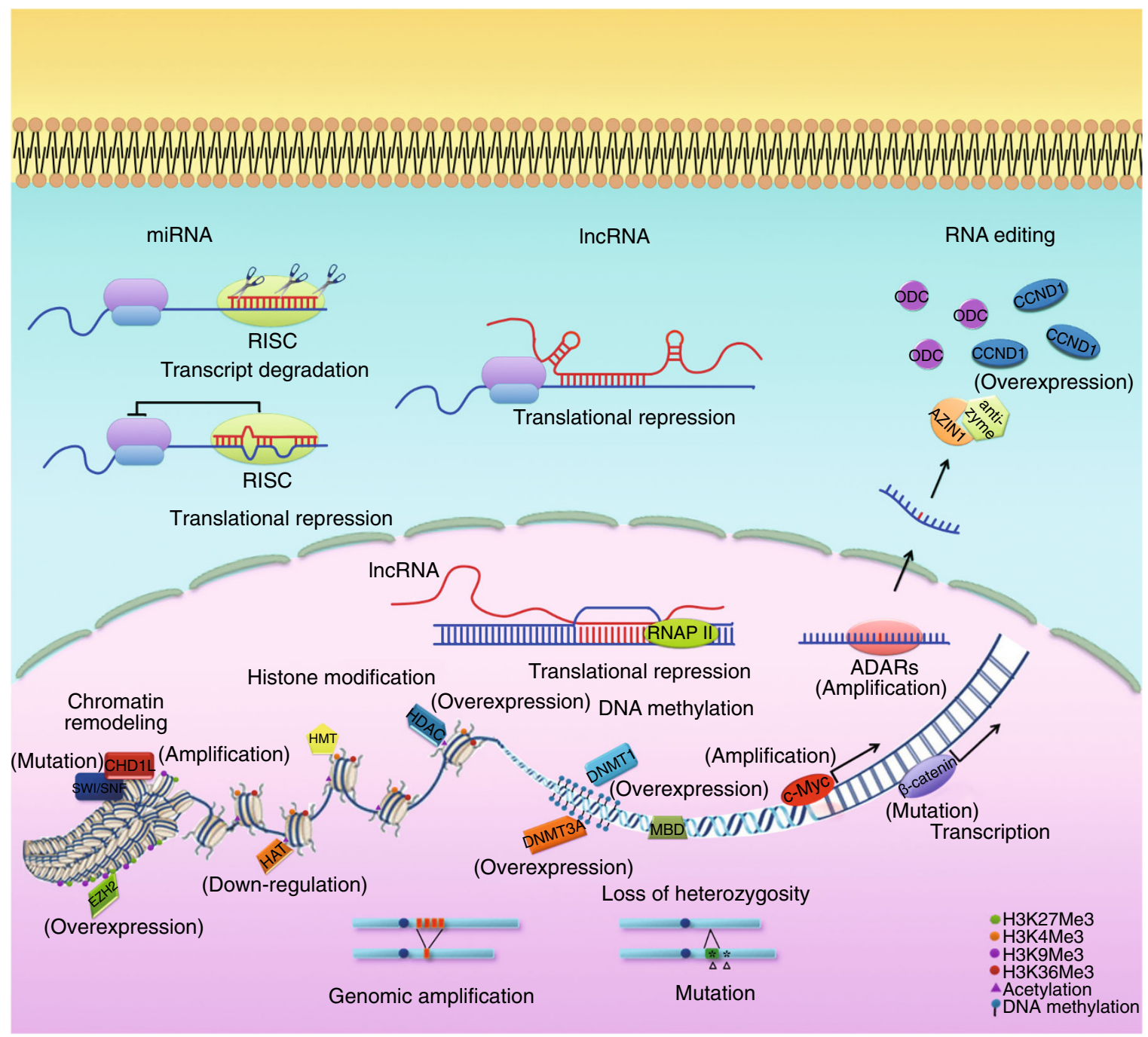

Figure 2. Genetic and epigenetic alterations in HCC. Genetic and epigenetic alterations interplay during cancer initiation and progression. The alterations exist at multiple levels including large chromosomal gain or loss, single nucleotide variations or mutations, overexpression or down-regulation of miRNAs and IncRNAs, disrupted RNA editing events, hyperactivation or inactivation of chromatin remodeling components, and aberrant DNA methylation at the promoter region of critical tumor suppressor genes et al.

patients (Endo et al., 2013). In addition, the CHD family member Chromodomain helicase DNA binding 1 like (CHD1L) has been proven to have diverse oncogenic roles in hepatocarcinogenesis (Chen et al., 2010).

\section{Long non-coding RNAs (IncRNAs)}

A large number of non-protein coding transcripts exist in the genome. In the past, those long non-coding RNAs were considered as "rubbish" of the genome for their unknown functions. Recently, emerging evidences suggested that IncRNAs might play important roles in regulating gene expression at post-transcriptional level. LncRNAs can regulate gene transcription either through directly binding to the RNA polymerase II, or modifying the activity of the transcriptional co-regulators (Mercer et al., 2009). In addition to transcriptional regulation, IncRNAs can also control the post-transcriptional mRNA processing such as mRNA splicing and translation. Furthermore, IncRNAs were also reported to be involved in regulating histone methylation and chromatin remodeling, which are the most important epigenetic regulatory machinery in regulating gene expression (Guttman and Rinn 2012). Altered expression of IncRNAs has been observed in tumors including HCC and they are suggested to play critical roles during tumorigenesis. High expression of IncRNA-HEIH is significantly associated with $\mathrm{HCC}$ recurrence and poor prognosis. In vitro and in vivo functional studies revealed that the overexpression of IncRNA-HEIH can promote HCC tumorigenesis and might function through EZH2 (Yang et al., 2011a). In addition, 
overexpression of Long Non-coding RNA HOTAIR and MALAT-1 could help predict tumor recurrence and prognosis of HCC patients (Lai et al., 2012; Yang et al., 2011b). All these evidences indicated that IncRNAs might be important in $\mathrm{HCC}$ initiation and progression.

\section{SUMMARY AND PERSPECTIVES}

Like other solid tumors, HCC is characterized with multiple hallmarks including sustained proliferation, evading growth suppressive signals, metastasis to other organs, promoting angiogenesis, tumor-promoting microenvironment, cancer stem cell properties, and energy metabolism switch, etc. Genetic and epigenetic alterations interplay during cancer initiation and progression. The genomic changes vary from large chromosomal gain or loss to single nucleotide variations or mutations. Genetic alterations are irreversible alterations, which could be observed as early as in the preneoplastic stages. The early onset of genetic alterations indicated that they might be the tumor initiating steps in the development of cancer. Chromosome instability is the most common type of genetic alteration. Chromosome $1 \mathrm{q}$ and $8 \mathrm{q}$ are frequently amplified, while chromosome $1 p, 4 q, 6 q, 9 p$, $16 p, 16 q$, and $17 p$ are frequently lost in HCC. Those hot regions usually harbor important oncogenes or tumor suppressor genes, which might significantly contribute to hepatocarcinogenesis. In addition to large chromosomal segmental changes, single nucleotide changes in the genome also make a substantial contribution to cancer progression. Nucleotide changes known as mutations or variations can lead to either gain-of-function or loss-offunction of oncogenes and tumor suppressor genes. Noncoding nucleotide changes can also affect gene transcription, and post-transcriptional regulations of critical tumor related genes, which may directly trigger oncogenesis or enhance cancer risk. Epigenetic alteration is another important mechanism for oncogenesis. Epigenetic regulation includes a wide range of regulations at transcriptional or post-transcriptional levels, such as DNA methylation, histone modification, chromatin remodeling, and IncRNAs. Alterations at the epigenetic regulation machinery may lead to disrupted gene expression, which can also cause the activation of oncogenes or inactivation of tumor suppressor genes. The genetic and epigenetic alterations in HCC are summarized in Fig. 2. Small molecules or monoclonal antibodies, which specifically target the altered onco-proteins, have already been proven to be efficient in treating several types of cancer. For example, imatinib, which specifically target the BCR-ABL fusion kinase, is used in treating chronic myeloid leukemia; transtuzumab, a monoclonal antibody targeting the amplified tyrosine kinase receptor HER2, is used to treat advanced-stage breast cancer. However, the targeted therapies which are effective in treating $\mathrm{HCC}$ are still limited. Better understanding and characterization of novel genetic and epigenetic alterations, which are important to hepatocarcinogenesis, may help understand the molecular pathogenesis of $\mathrm{HCC}$, as well as providing novel therapeutic targets for HCC treatment.

\section{ACKNOWLEDGEMENTS}

This work was supported by Hong Kong Research Grant Council (RGC) General Research Fund (HKU/7668/11M), RGC Collaborative Research Funds (HKU7/CRG/09, HKBU5/CRG/10 and HKU3/ CRF/11R), Hong Kong Theme-based Research Scheme fund (T12403/11), and grants from National Basic Research Program (973 Program) (No. 2012CB967001) and the National Natural Science Foundation of China (Grant Nos. 81272416 and 81172338).

\section{ABBREVIATIONS}

Ang2, angiopoietin-2; bFGF, basic fibroblast growth factor; $\mathrm{CGH}$, comparative genomic hybridization; CSC, cancer stem cell; ECM, extracellular matrix; GWAS, genome-wide association study; HCC, hepatocellular carcinoma; HGF, hepatoctye growth factor; IncRNAs, long non-coding RNAs; $\mathrm{LOH}$, loss of heterozygosity; MMP, matrix metalloproteinases; PDGF, platelet-derived growth factor; RIZ1, Rbinteracting zinc finger 1; TAM, tumor associated macrophage; TCA, tricarboxylic acid.

\section{COMPLIANCE WITH ETHICS GUIDELINES}

Ming Liu, Lingxi Jiang, and Xin-Yuan Guan declare that they have no conflict of interest. This article does not contain any studies with human or animal subjects performed by the any of the authors.

\section{OPEN ACCESS}

This article is distributed under the terms of the Creative Commons Attribution License which permits any use, distribution, and reproduction in any medium, provided the original author(s) and the source are credited.

\section{REFERENCES}

Adams JM, Cory S (2007) The Bcl-2 apoptotic switch in cancer development and therapy. Oncogene 26:1324-1337

Antoniou AC, Beesley J, McGuffog L, Sinilnikova OM, Healey S, Neuhausen SL, Ding YC, Rebbeck TR, Weitzel JN, Lynch HT et al (2010) Common breast cancer susceptibility alleles and the risk of breast cancer for BRCA1 and BRCA2 mutation carriers: implications for risk prediction. Cancer Res 70:9742-9754

Arii S, Mise M, Harada M, Furutani M, Ishigami S, Niwano M, Mizumoto M, Fukumoto M, Imamura M (1996) Overexpression of matrix metalloproteinase 9 gene in hepatocellular carcinoma with invasive potential. Hepatology 24:316-322

Armeanu S, Pathil A, Venturelli S, Mascagni P, Weiss TS, Gottlicher M, Gregor M, Lauer UM, Bitzer M (2005) Apoptosis on hepatoma cells but not on primary hepatocytes by histone deacetylase inhibitors valproate and ITF2357. J Hepatol 42:210-217

Athanasiadis A, Rich A, Maas S (2004) Widespread A-to-I RNA editing of Alu-containing mRNAs in the human transcriptome. PLoS Biol 2:e391 
Ben-Porath I, Thomson MW, Carey VJ, Ge R, Bell GW, Regev A, Weinberg RA (2008) An embryonic stem cell-like gene expression signature in poorly differentiated aggressive human tumors. Nat Genet 40:499-507

Beyoglu D, Imbeaud S, Maurhofer O, Bioulac-Sage P, ZucmanRossi J, Dufour JF, Idle JR (2013) Tissue metabolomics of hepatocellular carcinoma: tumor energy metabolism and the role of transcriptomic classification. Hepatology 58:229-238

Bingle L, Brown NJ, Lewis CE (2002) The role of tumour-associated macrophages in tumour progression: implications for new anticancer therapies. J Pathol 196:254-265

Budhu A, Jia HL, Forgues M, Liu CG, Goldstein D, Lam A, Zanetti $K A$, Ye QH, Qin LX, Croce CM et al (2008) Identification of metastasis-related microRNAs in hepatocellular carcinoma. Hepatology 47:897-907

Cairns RA, Harris IS, Mak TW (2011) Regulation of cancer cell metabolism. Nat Rev Cancer 11:85-95

Calvisi DF, Ladu S, Gorden A, Farina M, Lee JS, Conner EA, Schroeder I, Factor VM, Thorgeirsson SS (2007) Mechanistic and prognostic significance of aberrant methylation in the molecular pathogenesis of human hepatocellular carcinoma. J Clin Invest 117:2713-2722

Carmeliet P, Jain RK (2000) Angiogenesis in cancer and other diseases. Nature 407:249-257

Cavallaro U, Christofori G (2004) Cell adhesion and signalling by cadherins and Ig-CAMs in cancer. Nat Rev Cancer 4:118-132

Chan THM, Chen LL, Liu M, Hu L, Zheng BJ, Poon VKM, Huang PZ, Yuan YF, Huang JD, Yang J et al (2012) Translationally controlled tumor protein induces mitotic defects and chromosome missegregation in hepatocellular carcinoma development. Hepatology 55:491-505

Chan TH, Lin CH, Qi L, Fei J, Li Y, Yong KJ, Liu M, Song Y, Chow $\mathrm{RK}, \mathrm{Ng} \mathrm{VH}$ et al (2013) A disrupted RNA editing balance mediated by ADARs (adenosine deaminases that act on RNA) in human hepatocellular carcinoma. Gut 63(5):832-843

Chang Y, Yan W, He XX, Zhang LM, Li CJ, Huang H, Nace G, Geller DA, Lin JS, Tsung A (2012) miR-375 inhibits autophagy and reduces viability of hepatocellular carcinoma cells under hypoxic conditions. Gastroenterology 143:177.e8-187.e8

Chen YC, Lin MC, Yao H, Wang H, Zhang AQ, Yu J, Hui CK, Lau GK, He ML, Sung J et al (2007) Lentivirus-mediated RNA interference targeting enhancer of zeste homolog 2 inhibits hepatocellular carcinoma growth through down-regulation of stathmin (vol. 46, p. 200, 2007). Hepatology 46:1314

Chen LL, Hu L, Chan THM, Tsao GSW, Xie D, Huo KK, Fu L, Ma S, Zheng BJ, Guan XY (2009a) Chromodomain helicase/adenosine triphosphatase DNA binding protein 1-like (CHD1L) gene suppresses the nucleus-to-mitochondria translocation of Nur77 to sustain hepatocellular carcinoma cell survival. Hepatology 50:122-129

Chen MH, Huang JD, Hu L, Zheng BJ, Chen LL, Tsang SL, Guan XY (2009b) Transgenic CHD1L expression in mouse induces spontaneous tumors. PLoS One 4(8):e6727

Chen LL, Chan THM, Yuan YF, Hu L, Huang J, Ma S, Wang J, Dong SS, Tang KH, Xie D et al (2010) CHD1L promotes hepatocellular carcinoma progression and metastasis in mice and is associated with these processes in human patients. J Clin Invest 120:11781191

Chen LL, Yuan YF, Li Y, Chan THM, Zheng BJ, Huang J, Guan XY (2011) Clinical significance of CHD1L in hepatocellular carcinoma and therapeutic potentials of virus-mediated $\mathrm{CHD} 1 \mathrm{~L}$ depletion. Gut 60:534-543

Chen LL, Li Y, Lin CH, Chan THM, Chow RKK, Song YY, Liu M, Yuan YF, Fu L, Kong KL et al (2013) Recoding RNA editing of AZIN1 predisposes to hepatocellular carcinoma. Nat Med 19:209-216

Chochi Y, Kawauchi S, Nakao M, Furuya T, Hashimoto K, Oga A, Oka M, Sasaki K (2009) A copy number gain of the $6 p$ arm is linked with advanced hepatocellular carcinoma: an array-based comparative genomic hybridization study. J Pathol 217:677-684

Colombino M, Sperlongano P, Izzo F, Tatangelo F, Botti G, Lombardi A, Accardo M, Tarantino L, Sordelli I, Agresti M et al (2012) BRAF and PIK3CA genes are somatically mutated in hepatocellular carcinoma among patients from South Italy. Cell Death Dis 3: e259

Datta J, Kutay H, Nasser MW, Nuovo GJ, Wang B, Majumder S, Liu CG, Volinia S, Croce CM, Schmittgen TD et al (2008) Methylation mediated silencing of microRNA-1 gene and its role in hepatocellular carcinogenesis. Cancer Res 68:5049-5058

Ding T, Xu J, Wang F, Shi M, Zhang Y, Li SP, Zheng LM (2009) High tumor-infiltrating macrophage density predicts poor prognosis in patients with primary hepatocellular carcinoma after resection. Hum Pathol 40:381-389

Ding J, Huang SL, Wu SQ, Zhao YJ, Liang LH, Yan MX, Ge C, Yao J, Chen TY, Wan DF et al (2010) Gain of miR-151 on chromosome 8q24.3 facilitates tumour cell migration and spreading through downregulating RhoGDIA. Nat Cell Biol 12:390-399

Ding J, Huang SL, Wang Y, Tian Q, Zha RP, Shi HB, Wang QF, Ge C, Chen TY, Zhao YJ et al (2013) Genome-wide screening reveals that miR-195 targets the TNF-/NF-B pathway by downregulating IB kinase alpha and TAB3 in hepatocellular carcinoma. Hepatology 58:654-666

El Tayebi HM, Omar K, Hegy S, El Maghrabi M, El Brolosy M, Hosny KA, Esmat G, Abdelaziz Al (2013) Repression of miR-17-5p with elevated expression of E2F-1 and C-MYC in non-metastatic hepatocellular carcinoma and enhancement of cell growth upon reversing this expression pattern. Biochem Biophys Res Commun 434:421-427

El-Serag HB, Rudolph KL (2007) Hepatocellular carcinoma: epidemiology and molecular carcinogenesis. Gastroenterology 132:2557-2576

Endo M, Yasui K, Zen Y, Gen Y, Zen K, Tsuji K, Dohi O, Mitsuyoshi $\mathrm{H}$, Tanaka S, Taniwaki M et al (2013) Alterations of the SWI/SNF chromatin remodelling subunit-BRG1 and BRM in hepatocellular carcinoma. Liver Int 33:105-117

Fang W, Piao Z, Simon D, Sheu JC, Huang S (2000) Mapping of a minimal deleted region in human hepatocellular carcinoma to 1p36.13-p36.23 and mutational analysis of the RIZ (PRDM2) gene localized to the region. Genes chromosomes cancer 28:269-275

Farber E (1984) The multistep nature of cancer development. Cancer Res 44:4217-4223 
Fattovich G, Giustina G, Degos F, Tremolada F, Diodati G, Almasio P, Nevens F, Solinas A, Mura D, Brouwer JT et al (1997) Morbidity and mortality in compensated cirrhosis type $\mathrm{C}$ : a retrospective follow-up study of 384 patients. Gastroenterology 112:463-472

Finn RS, Zhu AX (2009) Targeting angiogenesis in hepatocellular carcinoma: focus on VEGF and bevacizumab. Expert Rev Anticancer Ther 9:503-509

Fiume L, Manerba M, Vettraino M, Di Stefano G (2011) Effect of sorafenib on the energy metabolism of hepatocellular carcinoma cells. Eur J Pharmacol 670:39-43

Fodde R, Brabletz T (2007) Wnt/beta-catenin signaling in cancer stemness and malignant behavior. Curr Opin Cell Biol 19:150158

Fornari F, Gramantieri L, Ferracin M, Veronese A, Sabbioni S, Calin GA, Grazi GL, Giovannini C, Croce CM, Bolondi L et al (2008) MiR-221 controls CDKN1C/p57 and CDKN1B/p27 expression in human hepatocellular carcinoma. Oncogene 27:5651-5661

Fornari F, Milazzo M, Chieco P, Negrini M, Calin GA, Grazi GL, Pollutri D, Croce CM, Bolondi L, Gramantieri L (2010) MiR-199a$3 p$ Regulates mTOR and c-Met to influence the doxorubicin sensitivity of human hepatocarcinoma cells. Cancer Res 70:5184-5193

Fu L, Dong SS, Xie YW, Tai LS, Chen L, Kong KL, Man K, Xie D, Li $Y$, Cheng $Y$ et al (2010) Down-regulation of tyrosine aminotransferase at a frequently deleted region $16 q 22$ contributes to the pathogenesis of hepatocellular carcinoma. Hepatology 51:16241634

Fujimoto A, Totoki Y, Abe T, Boroevich KA, Hosoda F, Nguyen $\mathrm{HH}$, Aoki M, Hosono N, Kubo M, Miya F et al (2012) Whole-genome sequencing of liver cancers identifies etiological influences on mutation patterns and recurrent mutations in chromatin regulators. Nat Genet 44:760-764

Fujiwara Y, Hoon DS, Yamada T, Umeshita K, Gotoh M, Sakon M, Nishisho I, Monden M (2000) PTEN / MMAC1 mutation and frequent loss of heterozygosity identified in chromosome $10 q$ in a subset of hepatocellular carcinomas. JJpn J Cancer Res 91:287292

Giannelli G, Bergamini C, Marinosci F, Fransvea E, Quaranta M, Lupo L, Schiraldi O, Antonaci S (2002) Clinical role of MMP-2/ TIMP-2 imbalance in hepatocellular carcinoma. Int $\mathrm{J}$ Cancer 97:425-431

Gott JM, Emeson RB (2000) Functions and mechanisms of RNA editing. Annu Rev Genet 34:499-531

Gramantieri L, Ferracin M, Fornari F, Veronese A, Sabbioni S, Liu CG, Calin GA, Giovannini C, Ferrazzi E, Grazi GL et al (2007) Cyclin g1 is a target of miR-122a, a microRNA frequently downregulated in human hepatocellular carcinoma. Cancer Res 67:6092-6099

Gramantieri L, Fornari F, Ferracin M, Veronese A, Sabbioni S, Calin GA, Grazi GL, Croce CM, Bolondi L, Negrini M (2009) MicroRNA221 targets Bmf in hepatocellular carcinoma and correlates with tumor multifocality. Clin Cancer Res 15:5073-5081

Guan XY, Fang Y, Sham JST, Kwong DLW, Zhang YQ, Liang QW, Li HM, Zhou H, Trent JM (2000) Recurrent chromosome alterations in hepatocellular carcinoma detected by comparative genomic hybridization. Genes Chromosomes Cancer 29:110-116
Guichard C, Amaddeo G, Imbeaud S, Ladeiro Y, Pelletier L, Ben Maad I, Calderaro J, Bioulac-Sage P, Letexier M, Degos F et al (2012) Integrated analysis of somatic mutations and focal copynumber changes identifies key genes and pathways in hepatocellular carcinoma. Nat Genet 44:694-698

Guttman M, Rinn JL (2012) Modular regulatory principles of large non-coding RNAs. Nature 482(7385):339-346

Hagiwara A, Cornu M, Cybulski N, Polak P, Betz C, Trapani F, Terracciano L, Heim MH, Ruegg MA, Hall MN (2012) Hepatic mTORC2 activates glycolysis and lipogenesis through Akt, glucokinase, and SREBP1c. Cell Metab 15:725-738

Hanahan D, Weinberg RA (2000) The hallmarks of cancer. Cell 100:57-70

Hanahan D, Weinberg RA (2011) Hallmarks of cancer: the next generation. Cell 144:646-674

He XX, Chang Y, Meng FY, Wang MY, Xie QH, Tang F, Li PY, Song YH, Lin JS (2012) MicroRNA-375 targets AEG-1 in hepatocellular carcinoma and suppresses liver cancer cell growth in vitro and in vivo. Oncogene 31:3357-3369

Hendrich B, Bird A (1998) Identification and characterization of a family of mammalian methyl-CpG binding proteins. Mol Cell Biol 18:6538-6547

Hengartner MO (2000) The biochemistry of apoptosis. Nature 407:770-776

Henry JC, Park JK, Jiang JM, Kim JH, Nagorney DM, Roberts LR, Banerjee S, Schmittgen TD (2010) miR-199a-3p targets CD44 and reduces proliferation of CD44 positive hepatocellular carcinoma cell lines. Biochem Biophys Res Commun 403:120-125

Hernandez-Gea V, Toffanin S, Friedman SL, Llovet JM (2013) Role of the microenvironment in the pathogenesis and treatment of hepatocellular carcinoma. Gastroenterology 144:512-527

Higashitsuji $\mathrm{H}$, Itoh K, Nagao T, Dawson S, Nonoguchi K, Kido T, Mayer RJ, Arii S, Fujita J. (2000). Reduced stability of retinoblastoma protein by gankyrin, an oncogenic ankyrinrepeat protein overexpressed in hepatomas. Nat Med 6(1):96-99

Hsu PP, Sabatini DM (2008) Cancer cell metabolism: Warburg and beyond. Cell 134:703-707

Hu L, Liu M, Chen LL, Chan THM, Wang J, Huo KK, Zheng BJ, Xie D, Guan XY (2012) SCYL1 binding protein 1 promotes the ubiquitin-dependent degradation of Pirh2 and has tumor-suppressive function in the development of hepatocellular carcinoma. Carcinogenesis 33:1581-1588

Hussain SP, Schwank J, Staib F, Wang XW, Harris CC (2007) TP53 mutations and hepatocellular carcinoma: insights into the etiology and pathogenesis of liver cancer. Oncogene 26:2166-2176

Iwata N, Yamamoto H, Sasaki S, Itoh F, Suzuki H, Kikuchi T, Kaneto H, Iku S, Ozeki I, Karino Y et al (2000) Frequent hypermethylation of $\mathrm{CpG}$ islands and loss of expression of the 14-3-3 sigma gene in human hepatocellular carcinoma. Oncogene 19:5298-5302

Jablkowski M, Bocian A, Bialkowska J, Bartkowiak J (2005) A comparative study of P53/MDM2 genes alterations and P53/ MDM2 proteins immunoreactivity in liver cirrhosis and hepatocellular carcinoma. J Exp Clin Cancer Res 24:117-125

Ji JF, Yamashita T, Budhu A, Forgues M, Jia HL, Li CL, Deng CX, Wauthier E, Reid LM, Ye QH et al (2009) Identification of microRNA-181 by genome-wide screening as a critical player in 
EpCAM-positive hepatic cancer stem cells. Hepatology 50:472480

Ji J, Zhao L, Budhu A, Forgues M, Jia HL, Qin LX, Ye QH, Yu J, Shi $X$, Tang ZY et al (2010) Let-7g targets collagen type I alpha2 and inhibits cell migration in hepatocellular carcinoma. J Hepatol 52:690-697

Jiang DK, Sun JL, Cao GW, Liu Y, Lin DX, Gao YZ, Ren WH, Long $X D$, Zhang HX, Ma XP et al (2013) Genetic variants in STAT4 and HLA-DQ genes confer risk of hepatitis $B$ virus-related hepatocellular carcinoma. Nat Genet 45(1):72-75

Joyce JA (2005) Therapeutic targeting of the tumor microenvironment. Cancer Cell 7:513-520

Kanai Y, Ushijima S, Hui AM, Ochiai A, Tsuda H, Sakamoto M, Hirohashi S (1997) The E-cadherin gene is silenced by CpG methylation in human hepatocellular carcinomas. Int $\mathrm{J}$ Cancer 71:355-359

Kanai Y, Hui AM, Sun L, Ushijima S, Sakamoto M, Tsuda H, Hirohashi S (1999) DNA hypermethylation at the D17S5 locus and reduced HIC-1 mRNA expression are associated with hepatocarcinogenesis. Hepatology 29:703-709

Kim KW, Bae SK, Lee OH, Bae MH, Lee MJ, Park BC (1998) Insulinlike growth factor II induced by hypoxia may contribute to angiogenesis of human hepatocellular carcinoma. Cancer Res 58:348-351

Kim TM, Yim SH, Shin SH, Xu HD, Jung YC, Park CK, Choi JY, Park WS, Kwon MS, Fiegler $\mathrm{H}$ et al (2008) Clinical implication of recurrent copy number alterations in hepatocellular carcinoma and putative oncogenes in recurrent gains on 1q. Int $\mathrm{J}$ Cancer 123:2808-2815.

Kim J, Woo AJ, Chu JL, Snow JW, Fujiwara Y, Kim CG, Cantor AB, Orkin SH (2010) A Myc network accounts for similarities between embryonic stem and cancer cell transcription programs. Cell 143:313-324

Ko E, Kim SJ, Joh JW, Park CK, Park J, Kim DH (2008) CpG island hypermethylation of SOCS-1 gene is inversely associated with HBV infection in hepatocellular carcinoma. Cancer Lett 271:240250

Kondo Y, Kanai Y, Sakamoto M, Mizokami M, Ueda R, Hirohashi S (2000) Genetic instability and aberrant DNA methylation in chronic hepatitis and cirrhosis - A comprehensive study of loss of heterozygosity and microsatellite instability at 39 loci and DNA hypermethylation on $8 \mathrm{CpG}$ islands in microdissected specimens from patients with hepatocellular carcinoma. Hepatology 32:970979

Kouzarides T (2007) Chromatin modifications and their function. Cell 128:693-705

Kroemer G, Pouyssegur J (2008) Tumor cell metabolism: cancer's Achilles' heel. Cancer Cell 13:472-482

Kubbutat MHG, Jones SN, Vousden KH (1997) Regulation of p53 stability by Mdm2. Nature 387:299-303

Kumar V, Kato N, Urabe Y, Takahashi A, Muroyama R, Hosono N, Otsuka M, Tateishi R, Omata M, Nakagawa H et al (2011) Genome-wide association study identifies a susceptibility locus for HCV-induced hepatocellular carcinoma. Nat Genet 43:455458

Kuroki T, Fujiwara Y, Nakamori S, Imaoka S, Kanematsu T, Nakamura $Y$ (1995) Evidence for the presence of two tumour- suppressor genes for hepatocellular carcinoma on chromosome 13q. Br J Cancer 72:383-385

Lai MC, Yang Z, Zhou L, Zhu QQ, Xie HY, Zhang F, Wu LM, Chen LM, Zheng SS (2012) Long non-coding RNA MALAT-1 overexpression predicts tumor recurrence of hepatocellular carcinoma after liver transplantation. Med Oncol 29:1810-1816

Lang QB, Ling CQ (2012) MiR-124 suppresses cell proliferation in hepatocellular carcinoma by targeting PIK3CA. Biochem Biophys Res Commun 426:247-252

Law PTY, Ching AKK, Chan AWH, Wong QWL, Wong CK, To KF, Wong N (2012) MiR-145 modulates multiple components of the insulin-like growth factor pathway in hepatocellular carcinoma. Carcinogenesis 33:1134-1141

Lee S, Lee HJ, Kim JH, Lee HS, Jang JJ, Kang GH (2003) Aberrant CpG island hypermethylation along multistep hepatocarcinogenesis. Am J Pathol 163:1371-1378

Lee TK, Poon RTP, Yuen AP, Ling MT, Kwok WK, Wang XH, Wong YC, Guan XY, Man K, Chau KL et al (2006) Twist overexpression correlates with hepatocellular carcinoma metastasis through induction of epithelial-mesenchymal transition. Clin Cancer Res 12:5369-5376

Lee TK, Castilho A, Cheung VC, Tang KH, Ma S, Ng IO (2011) CD24 $(+)$ liver tumor-initiating cells drive self-renewal and tumor initiation through STAT3-mediated NANOG regulation. Cell Stem Cell 9:50-63

Lemmon MA, Schlessinger J (2010) Cell signaling by receptor tyrosine kinases. Cell 141:1117-1134

Levine AJ, Puzio-Kuter AM (2010) The control of the metabolic switch in cancers by oncogenes and tumor suppressor genes. Science 330:1340-1344

Li N, Fu H, Tie Y, Hu Z, Kong W, Wu Y, Zheng X (2009) miR-34a inhibits migration and invasion by down-regulation of c-Met expression in human hepatocellular carcinoma cells. Cancer Lett 275:44-53

Li J, Fu H, Xu C, Tie Y, Xing R, Zhu J, Qin Y, Sun Z, Zheng X (2010) miR-183 inhibits TGF-beta1-induced apoptosis by downregulation of PDCD4 expression in human hepatocellular carcinoma cells. BMC Cancer 10:354

Li M, Zhao H, Zhang X, Wood LD, Anders RA, Choti MA, Pawlik TM, Daniel HD, Kannangai R, Offerhaus GJ et al (2011) Inactivating mutations of the chromatin remodeling gene ARID2 in hepatocellular carcinoma. Nat Genet 43:828-829

Li SP, Qian J, Yang Y, Zhao WT, Dai JC, Bei JX, Foo JN, McLaren PJ, Li ZQ, Yang JM et al (2012) GWAS identifies novel susceptibility loci on $6 \mathrm{p} 21.32$ and $21 \mathrm{q} 21.3$ for hepatocellular carcinoma in chronic hepatitis B virus carriers. PLoS Genet 8(7): e1002791

Li CF, Wang YZ, Wang SF, Wu B, Hao JL, Fan HX, Ju Y, Ding YP, Chen LZ, Chu XY et al (2013a) Hepatitis B virus mRNA-mediated miR-122 inhibition upregulates PTTG1-binding protein, which promotes hepatocellular carcinoma tumor growth and cell invasion. J Virol 87:2193-2205

Li Y, Chen LL, Chan THM, Guan XY (2013b) Hepatocellular carcinoma: transcriptome diversity regulated by RNA editing. Int J Biochem Cell B 45:1843-1848

Li J, Quan H, Liu Q, Si Z, He Z, Qi H (2013c) Alterations of axis inhibition protein 1 (AXIN1) in hepatitis $B$ virus-related 
hepatocellular carcinoma and overexpression of AXIN1 induces apoptosis in hepatocellular cancer cells. Oncol Res 20:281-288

Liu WH, Yeh SOH, Lu CC, Yu SL, Chen HY, Lin CY, Chen DS, Chen PJ (2009) MicroRNA-18a prevents estrogen receptor-alpha expression, promoting proliferation of hepatocellular carcinoma cells. Gastroenterology 136:683-693

Liu AM, Poon RTP, Luk JM (2010) MicroRNA-375 targets Hipposignaling effector YAP in liver cancer and inhibits tumor properties. Biochem Biophys Res Commun 394:623-627

Liu M, Chen LL, Chan THM, Wang J, Li Y, Li Y, Zeng TT, Yuan YF, Guan XY (2012) Serum and glucocorticoid kinase 3 at 8q13.1 promotes cell proliferation and survival in hepatocellular carcinoma. Hepatology 55:1754-1765

Liu L, Dai Y, Chen J, Zeng T, Li Y, Chen L, Zhu YH, Li J, Xie D, Yuan YF et al (2013) Maelstrom promotes hepatocellular carcinoma metastasis by inducing epithelial-mesenchymal transition via Akt/ GSK-3beta/snail signaling. Hepatology 59(2):531-543

Liu M, Li Y, Chen L, Chan THM, Song Y, Fu L, Zeng TT, Dai YD, Zhu $\mathrm{YH}$, Li Y et al (2014) Allele-specific imbalance of oxidative stressinduced growth inhibitor 1 associates with progression of hepatocellular carcinoma. Gastroenterology 146(4):1084-1096

Luedde T (2010) MicroRNA-151 and its hosting gene FAK (focal adhesion kinase) regulate tumor cell migration and spreading of hepatocellular carcinoma. Hepatology 52:1164-1166

Ma S, Chan KW, Hu L, Lee TK, Wo JY, Ng IO, Zheng BJ, Guan XY (2007) Identification and characterization of tumorigenic liver cancer stem/progenitor cells. Gastroenterology 132:2542-2556

Ma NF, Hu L, Fung JM, Xie D, Zheng BJ, Chen LL, Tang DJ, Fu L, Wu Z, Chen $M$ et al (2008) Isolation and characterization of a novel oncogene, amplified in liver cancer 1, within a commonly amplified region at $1 \mathrm{q} 21$ in hepatocellular carcinoma. Hepatology 47:503-510

Ma S, Tang KH, Chan YP, Lee TK, Kwan PS, Castilho A, Ng I, Man $\mathrm{K}$, Wong N, To KF et al (2010) miR-130b promotes CD133(+) liver tumor-initiating cell growth and self-renewal via tumor protein 53-induced nuclear protein 1. Cell Stem Cell 7:694-707

Marquardt JU, Raggi C, Andersen JB, Seo D, Avital I, Geller D, Lee YH, Kitade M, Holczbauer A, Gillen MC et al (2011) Human hepatic cancer stem cells are characterized by common stemness traits and diverse oncogenic pathways. Hepatology 54:1031-1042

Meng FY, Henson R, Wehbe-Janek H, Ghoshal K, Jacob ST, Patel T (2007) MicroRNA-21 regulates expression of the PTEN tumor suppressor gene in human hepatocellular cancer. Gastroenterology 133:647-658

Mercer TR, Dinger ME, Mattick JS (2009) Long non-coding RNAs: insights into functions. Nat Rev Genet 10:155-159

Merle P, De La Monte S, Kim M, Herrmann M, Tanaka S, Von dem Bussche A, Kew MC, Trepo C, Wands JR (2004) Functional consequences of frizzled-7 receptor overexpression in human hepatocellular carcinoma. Gastroenterology 127:1110-1122

Mise M, Arii S, Higashituji $H$, Furutani M, Niwano M, Harada T, Ishigami SI, Toda Y, Nakayama H, Fukumoto M et al (1996) Clinical significance of vascular endothelial growth factor and basic fibroblast growth factor gene expression in liver turner. Hepatology 23:455-464

Mishra L, Banker T, Murray J, Byers S, Thenappan A, He AR, Shetty K, Johnson L, Reddy EP (2009) Liver stem cells and hepatocellular carcinoma. Hepatology 49:318-329
Miyoshi Y, Iwao K, Nagasawa Y, Aihara T, Sasaki Y, Imaoka S, Murata M, Shimano T, Nakamura $Y$ (1998) Activation of the betacatenin gene in primary hepatocellular carcinomas by somatic alterations involving exon 3. Cancer Res 58:2524-2527

Mizuno S, Chijiwa T, Okamura T, Akashi K, Fukumaki Y, Niho Y, Sasaki $H$ (2001) Expression of DNA methyltransferases DNMT1, $3 \mathrm{~A}$, and $3 \mathrm{~B}$ in normal hematopoiesis and in acute and chronic myelogenous leukemia. Blood 97:1172-1179

Momparler RL (2003) Cancer epigenetics. Oncogene 22:6479-6483

Murakami Y, Tamori A, Itami S, Tanahashi T, Toyoda H, Tanaka M, Wu WH, Brojigin N, Kaneoka Y, Maeda A et al (2013) The expression level of miR-18b in hepatocellular carcinoma is associated with the grade of malignancy and prognosis. BMC Cancer 13:99

Nishida N, Fukuda Y, Kokuryu H, Toguchida J, Yandell DW, Ikenega M, Imura H, Ishizaki K (1993) Role and mutational heterogeneity of the P53-gene in hepatocellular-carcinoma. Cancer Res 53:368-372

Nishida N, Fukuda Y, Komeda T, Kita R, Sando T, Furukawa M, Amenomori M, Shibagaki I, Nakao K, Ikenaga M et al (1994) Amplification and overexpression of the cyclin D1 gene in aggressive human hepatocellular carcinoma. Cancer Res 54:3107-3110

Nishimura T, Nishida N, Itoh T, Komeda T, Fukuda Y, Ikai I, Yamaoka Y, Nakao K (2005) Discrete breakpoint mapping and shortest region of overlap of chromosome arm $1 q$ gain and $1 p$ loss in human hepatocellular carcinoma detected by semiquantitative microsatellite analysis. Genes Chromosomes Cancer 42:34-43

Noh JH, Chang YG, Kim MG, Jung KH, Kim JK, Bae HJ, Eun JW, Shen Q, Kim SJ, Kwon SH et al (2013) MiR-145 functions as a tumor suppressor by directly targeting histone deacetylase 2 in liver cancer. Cancer Lett 335:455-462

Oh BK, Kim H, Park HJ, Shim YH, Choi J, Park C, Park YN (2007) DNA methyltransferase expression and DNA methylation in human hepatocellular carcinoma and their clinicopathological correlation. Int J Mol Med 20:65-73

Oka Y, Waterland RA, Killian JK, Nolan CM, Jang HS, Tohara K, Sakaguchi S, Yao T, Iwashita A, Yata Y et al (2002) M6P/IGF2R tumor suppressor gene mutated in hepatocellular carcinomas in Japan. Hepatology 35:1153-1163

Okamoto H, Yasui K, Zhao C, Arii S, Inazawa A (2003) PTK2 and EIF3S3 genes may be amplification targets at 8q23-q24 and are associated with large hepatocellular carcinomas. Hepatology 38:1242-1249

Okano M, Bell DW, Haber DA, Li E (1999) DNA methyltransferases Dnmt3a and Dnmt3b are essential for de novo methylation and mammalian development. Cell 99:247-257

Olivier M, Hollstein M, Hainaut P (2010) TP53 mutations in human cancers: origins, consequences, and clinical use. Cold Spring Harb Perspect Biol 2(1):a001008

Ozturk M (1991) P53 mutation in hepatocellular-carcinoma after aflatoxin exposure. Lancet 338:1356-1359

Parada LA, Hallen M, Tranberg KG, Hagerstrand I, Bondeson L, Mitelman F, Johansson B (1998) Frequent rearrangements of chromosomes 1,7 , and 8 in primary liver cancer. Genes Chromosomes Cancer 23:26-35

Parkin DM, Bray F, Ferlay J, Pisani P (2005) Global cancer statistics, 2002. CA Cancer J Clin 55:74-108 
Pathil A, Armeanu S, Venturelli S, Mascagni P, Weiss TS, Gregor M, Lauer UM, Bitzer M (2006) HDAC inhibitor treatment of hepatoma cells induces both TRAIL-independent apoptosis and restoration of sensitivity to TRAIL. Hepatology 43:425-434

Patil MA, Zhang J, Ho C, Cheung ST, Fan ST, Chen X (2006) Hedgehog signaling in human hepatocellular carcinoma. Cancer Biol Ther 5:111-117

Pei DQ, Kang TB, Qi HX (2000) Cysteine array matrix metalloproteinase (CA-MMP)/MMP-23 is a type II transmembrane matrix metalloproteinase regulated by a single cleavage for both secretion and activation. J Biol Chem 275:33988-33997

Reya T, Morrison SJ, Clarke MF, Weissman IL (2001) Stem cells, cancer, and cancer stem cells. Nature 414:105-111

Rousseau B, Menard L, Haurie V, Taras D, Blanc JF, MoreauGaudry F, Metzler P, Hugues M, Boyault S, Lemiere S et al (2007) Overexpression and role of the ATPase and putative DNA helicase RuvB-like 2 in human hepatocellular carcinoma. Hepatology 46:1108-1118

Rundhaug JE (2003) Matrix metalloproteinases, angiogenesis, and cancer-Commentary re: A. C. Lockhart et al., reduction of wound angiogenesis in patients treated with BMS-275291, a broad spectrum matrix metalloproteinase inhibitor. Clin Cancer Res 9:551-554

Saito $Y$, Kanai $Y$, Nakagawa T, Sakamoto $M$, Saito $H$, Ishii $H$, Hirohashi S (2003) DNA methyltransferase (DNMT) 1 protein expression is significantly increased in human hepatocellular carcinomas with malignant potential and may be a biological predictor of prognosis in hepatocellular carcinoma patients. Hepatology 38:593a-593a

Santoni-Rugiu E, Jensen MR, Thorgeirsson SS (1998) Disruption of the $\mathrm{pRb} / \mathrm{E} 2 \mathrm{~F}$ pathway and inhibition of apoptosis are major oncogenic events in liver constitutively expressing c-myc and transforming growth factor alpha. Cancer Res 58:123-134

Semela D, Dufour JF (2004) Angiogenesis and hepatocellular carcinoma. J Hepatol 41:864-880

Shachaf CM, Kopelman AM, Arvanitis C, Karlsson A, Beer S, Mandl S, Bachmann MH, Borowsky AD, Ruebner B, Cardiff RD et al (2004) MYC inactivation uncovers pluripotent differentiation and tumour dormancy in hepatocellular cancer. Nature 431:11121117

Shih TC, Tien YJ, Wen CJ, Yeh TS, Yu MC, Huang CH, Lee YS, Yen TC, Hsieh SY (2012) MicroRNA-214 downregulation contributes to tumor angiogenesis by inducing secretion of the hepatomaderived growth factor in human hepatoma. J Hepatol 57:584-591

Shiraki K, Sugimoto K, Fujikawa K, Yamanaka T, Takase K, Nakano T (2000) Survivin promotes cell proliferation in human hepatocellular carcinoma. Gastroenterology 118:A906-A906

Song K, Han C, Wu T (2012) Epigenetic regulation of miR-122 expression by PPAR gamma/RXR alpha complex and HBx in hepatocellular carcinoma. Hepatology 56:609a-610a

Stamenkovic I (2000) Matrix metalloproteinases in tumor invasion and metastasis. Semin Cancer Biol 10:415-433

Sudo T, Utsunomiya T, Mimori K, Nagahara H, Ogawa K, Inoue H, Wakiyama S, Fujita H, Shirouzu K, Mori M (2005) Clinicopathological significance of EZH2 mRNA expression in patients with hepatocellular carcinoma. $\mathrm{Br} \mathrm{J}$ Cancer 92:1754-1758
Sugimachi K, Tanaka S, Kameyama T, Taguchi KI, Aishima SI, Shimada M, Sugimachi K, Tsuneyoshi M (2003) Transcriptional repressor snail and progression of human hepatocellular carcinoma. Clin Cancer Res 9:2657-2664

Takehara T, Liu X, Fujimoto J, Friedman SL, Takahashi H (2001) Expression and role of $\mathrm{Bcl}-\mathrm{xL}$ in human hepatocellular carcinomas. Hepatology 34:55-61

Thorgeirsson SS, Grisham JW (2002) Molecular pathogenesis of human hepatocellular carcinoma. Nat Genet 31:339-346

Tsujiuchi T, Sugata E, Masaoka T, Onishi M, Fujii H, Shimizu K, Honoki K (2007) Expression and DNA methylation patterns of Tslc1 and Dal-1 genes in hepatocellular carcinomas induced by $\mathrm{N}$-nitrosodiethylamine in rats. Cancer Sci 98:943-948

Ueki T, Fujimoto J, Suzuki T, Yamamoto H, Okamoto E (1997) Expression of hepatocyte growth factor and its receptor, the c-met proto-oncogene, in hepatocellular carcinoma. Hepatology 25:619-623

Venook AP, Papandreou C, Furuse J, de Guevara LL (2010) The incidence and epidemiology of hepatocellular carcinoma: a global and regional perspective. Oncologist 15(Suppl 4):5-13

Vertino PM, Sekowski JA, Coll JM, Applegren N, Han S, Hickey RJ, Malkas LH (2002) DNMT1 is a component of a multiprotein DNA replication complex. Cell Cycle 1:416-423

Vogelstein B, Kinzler KW (1993) The multistep nature of cancer. Trends Genet 9:138-141

Voulgari A, Pintzas A (2009) Epithelial-mesenchymal transition in cancer metastasis: mechanisms, markers and strategies to overcome drug resistance in the clinic. BBA-Rev Cancer 1796:75-90

Wang G, Huang CH, Zhao Y, Cai L, Wang Y, Xiu SJ, Jiang ZW, Yang $S$, Zhao T, Huang W et al (2000) Genetic aberration in primary hepatocellular carcinoma: correlation between p53 gene mutation and loss-of-heterozygosity on chromosome 16q21-q23 and 9p21-p23. Cell Res 10:311-323

Wang Y, Wu MC, Sham JST, Zhang WG, Wu WQ, Guan XY (2002) Prognostic significance of c-myc and AIB1 amplification in hepatocellular carcinoma-a broad survey using high-throughput tissue microarray. Cancer-Am Cancer Soc 95:2346-2352

Wang GG, Allis CD, Chi P (2007a) Chromatin remodeling and cancer, part I: covalent histone modifications. Trends Mol Med 13:363-372

Wang GG, Allis CD, Chi P (2007b) Chromatin remodeling and cancer, Part II: ATP-dependent chromatin remodeling. Trends Mol Med 13:373-380

Wang Y, Lee ATC, Ma JZI, Wang JB, Ren JW, Yang YC, Tantoso E, Li KB, Ooi LLPJ, Tan P et al (2008) Profiling microRNA expression in hepatocellular carcinoma reveals microRNA-224 up-regulation and apoptosis inhibitor-5 as a microRNA-224specific target. J Biol Chem 283:13205-13215

Wang B et al (2010a) TGFbeta-mediated upregulation of hepatic miR-181b promotes hepatocarcinogenesis by targeting TIMP3. Oncogene 29:1787-1797

Wang Y, Lu YW, Toh ST, Sung WK, Tan P, Chow P, Chung AYF, Jooi LLP, Lee CGL (2010b) Lethal-7 is down-regulated by the hepatitis $B$ virus $x$ protein and targets signal transducer and activator of transcription 3. J Hepatol 53:57-66 
Wang L, Guo ZY, Zhang R, Xin B, Chen R, Zhao J, Wang T, Wen WH, Jia LT, Yao LB et al (2013a) Pseudogene OCT4-pg4 functions as a natural micro RNA sponge to regulate OCT4 expression by competing for miR-145 in hepatocellular carcinoma. Carcinogenesis 34:1773-1781

Wang R, Zhao N, Li S, Fang JH, Chen MX, Yang J, Jia WH, Yuan Y, Zhuang SM (2013b) MicroRNA-195 suppresses angiogenesis and metastasis of hepatocellular carcinoma by inhibiting the expression of VEGF, VAV2, and CDC42. Hepatology 58:642-653

Wei Y, Van Nhieu JT, Prigent S, Srivatanakul P, Tiollais P, Buendia MA (2002) Altered expression of E-cadherin in hepatocellular carcinoma: correlations with genetic alterations, beta-catenin expression, and clinical features. Hepatology 36:692-701

Whiteside TL (2008) The tumor microenvironment and its role in promoting tumor growth. Oncogene 27:5904-5912

Wong CM, Lee JMF, Ching YP, Jin DY, Ng IOL (2003) Genetic and epigenetic alterations of DLC-1 gene in hepatocellular carcinoma. Cancer Res 63:7646-7651

Wong QWL, Lung RWM, Law PTY, Lai PBS, Chan KYY, To KF, Wong N (2008) MicroRNA-223 is commonly repressed in hepatocellular carcinoma and potentiates expression of Stathmin1. Gastroenterology 135:257-269

Wong CCL, Wong CM, Tung EKK, Au SLK, Lee JMF, Poon RTP, Man K, Ng IOL (2011) The MICRORNA miR-139 suppresses metastasis and progression of hepatocellular carcinoma by down-regulating rho-kinase 2. Gastroenterology 140:322-331

Xia HP, Ooi LLPJ, Hui KM (2012) MiR-214 Targets beta-catenin pathway to suppress invasion, stem-like traits and recurrence of human hepatocellular carcinoma. PLoS One 7(9):e44206

Xiong YJ et al (2010) Effects of microRNA-29 on apoptosis, tumorigenicity, and prognosis of hepatocellular carcinoma. Hepatology 51:836-845

Xu T, Zhu Y, Xiong Y, Ge YY, Yun JP, Zhuang SM (2009) MicroRNA195 suppresses tumorigenicity and regulates G1/S transition of human hepatocellular carcinoma cells. Hepatology 50:113-121

Xu H, He JH, Xiao ZD, Zhang QQ, Chen YQ, Zhou H, Qu LH (2010) Liver-enriched transcription factors regulate microRNA-122 that targets CUTL1 during liver development. Hepatology 52:1431-1442

Xu X, Fan Z, Kang L, Han J, Jiang C, Zheng X, Zhu Z, Jiao H, Lin J, Jiang $K$ et al (2013) Hepatitis $B$ virus $X$ protein represses miRNA148a to enhance tumorigenesis. J Clin Invest 123:630-645

Yamashita T, Budhu A, Forgues M, Wang XW (2007) Activation of hepatic stem cell marker EpCAM by Wnt-beta-catenin signaling in hepatocellular carcinoma. Cancer Res 67:10831-10839

Yamashita T, Ji J, Budhu A, Forgues M, Yang W, Wang HY, Jia H, Ye Q, Qin LX, Wauthier E et al (2009) EpCAM-positive hepatocellular carcinoma cells are tumor-initiating cells with stem/progenitor cell features. Gastroenterology 136:1012-1024

Yancopoulos GD, Davis S, Gale NW, Rudge JS, Wiegand SJ, Holash J (2000) Vascular-specific growth factors and blood vessel formation. Nature 407:242-248

Yang B, Guo MZ, Herman JG, Clark DP (2003) Aberrant promoter methylation profiles of tumor suppressor genes in hepatocellular carcinoma. Am J Pathol 163:1101-1107

Yang ZF, Ho DW, Ng MN, Lau CK, Yu WC, Ngai P, Chu PW, Lam CT, Poon RT, Fan ST (2008) Significance of CD90+ cancer stem cells in human liver cancer. Cancer Cell 13:153-166
Yang F, Yin YX, Wang F, Wang YQ, Zhang L, Tang Y, Sun SH (2010) miR-17-5p promotes migration of human hepatocellular carcinoma cells through the P38 mitogen-activated protein kinaseheat shock protein 27 pathway. Hepatology 51:1614-1623

Yang F, Zhang L, Huo XS, Yuan JH, Xu D, Yuan SX, Zhu N, Zhou WP, Yang GS, Wang YZ et al (2011a) Long noncoding RNA high expression in hepatocellular carcinoma facilitates tumor growth through enhancer of zeste homolog 2 in humans. Hepatology 54:1679-1689

Yang Z, Zhou L, Wu LM, Lai MC, Xie HY, Zhang F, Zheng SS (2011b) Overexpression of long non-coding RNA HOTAIR predicts tumor recurrence in hepatocellular carcinoma patients following liver transplantation. Ann Surg Oncol 18:1243-1250

Yang X, Liang L, Zhang XF, Jia HL, Qin Y, Zhu XC, Gao XM, Qiao P, Zheng Y, Sheng YY et al (2013) MicroRNA-26a suppresses tumor growth and metastasis of human hepatocellular carcinoma by targeting interleukin-6-Stat3 pathway. Hepatology 58:158-170

Yao YJ, Ping XL, Zhang $\mathrm{H}$, Chen FF, Lee PK, Ahsan $\mathrm{H}$, Chen CJ, Lee $\mathrm{PH}$, Pleacocke M, Santella RM et al (1999) PTEN/MMAC1 mutations in hepatocellular carcinomas. Oncogene 18:31813185

Yasui K, Arii S, Zhao C, Imoto I, Ueda M, Nagai H, Emi M, Inazawa J (2002) TFDP1, CUL4A, and CDC16 identified as targets for amplification at $13 q 34$ in hepatocellular carcinomas. Hepatology 35:1476-1484

Yau WL, Lam CSC, Ng L, Chow AKM, Chan STC, Chan JYK, Wo JYH, Ng KTP, Man K, Poon RTP et al (2013) Over-expression of miR-106b promotes cell migration and metastasis in hepatocellular carcinoma by activating epithelial-mesenchymal transition process. PLoS One 8(3):e57882

Ye QH, Qin LX, Forgues M, He P, Kim JW, Peng AC, Simon R, Li Y, Robles Al, Chen YD et al (2003) Predicting hepatitis B viruspositive metastatic hepatocellular carcinomas using gene expression profiling and supervised machine learning. Nat Med 9:416423

Ying Q, Liang L, Guo W, Zha R, Tian Q, Huang S, Yao J, Ding J, Bao $M$, Ge C et al (2011) Hypoxia-inducible microRNA-210 augments the metastatic potential of tumor cells by targeting vacuole membrane protein 1 in hepatocellular carcinoma. Hepatology 54:2064-2075

Yoshiji H, Kuriyama S, Yoshii J, Ikenaka Y, Noguchi R, Hicklin DJ, Huber J, Nakatani T, Tsujinoue H, Yanase K et al (2002) Synergistic effect of basic fibroblast growth factor and vascular endothelial growth factor in murine hepatocellular carcinoma. Hepatology 35:834-842

Yoshikawa H, Matsubara K, Qian GS, Jackson P, Groopman JD, Manning JE, Harris CC, Herman JG (2001) SOCS-1, a negative regulator of the JAK/STAT pathway, is silenced by methylation in human hepatocellular carcinoma and shows growth-suppression activity. Nat Genet 28:29-35

Yuan BZ, Miller MJ, Keck CL, Zimonjic DB, Thorgeirsson SS, Popescu NC (1998) Cloning, characterization, and chromosomal localization of a gene frequently deleted in human liver cancer (DLC-1) homologous to rat RhoGAP. Cancer Res 58:2196-2199

Yuan F, Zhou W, Zou C, Zhang Z, Hu H, Dai Z, Zhang Y (2010) Expression of Oct4 in HCC and modulation to wnt/beta-catenin and TGF-beta signal pathways. Mol Cell Biochem 343:155-162 
Yuen MF, Hou JL, Chutaputti A (2009) Hepatocellular carcinoma in the Asia pacific region. J Gastroenterol Hepatol 24:346-353

Yuneva MO, Fan TWM, Allen TD, Higashi RM, Ferraris DV, Tsukamoto T, Mates JM, Alonso FJ, Wang CM, Seo Y et al (2012) The metabolic profile of tumors depends on both the responsible genetic lesion and tissue type. Cell Metab 15:157-170

Zhang XY, Liu SR, Hu TS, Liu SP, He Y, Sun SH (2009) Up-regulated MicroRNA-143 transcribed by nuclear factor kappa B enhances hepatocarcinoma metastasis by repressing fibronectin expression. Hepatology 50:490-499

Zhang YJ, Ahsan H, Chen Y, Lunn RM, Wang LY, Chen SY, Lee PH, Chen CJ, Santella RM (2002) High frequency of promoter hypermethylation of RASSF1A and p16 and its relationship to aflatoxin B1-DNA adduct levels in human hepatocellular carcinoma. Mol Carcinog 35:85-92

Zhang HX, Zhai Y, Hu ZB, Wu C, Qian J, Jia WH, Ma FC, Huang WF, Yu LX, Yue W et al (2010) Genome-wide association study identifies 1 p36.22 as a new susceptibility locus for hepatocellular carcinoma in chronic hepatitis B virus carriers. Nat Genet 42 (9):755-758

Zhang YZ, Takahashi S, Tasaka A, Yoshima T, Ochi H, Chayama K (2013) Involvement of microRNA-224 in cell proliferation, migration, invasion, and anti-apoptosis in hepatocellular carcinoma. J Gastroenterol Hepatol 28:565-575

Zhao XT, Li JJ, He YH, Lan F, Fu LL, Guo JY, Zhao RJ, Ye Y, He M, Chong WM et al (2001) A novel growth suppressor gene on chromosome 17p13.3 with a high frequency of mutation in human hepatocellular carcinoma. Cancer Res 61:7383-7387
Zheng F, Liao YJ, Cai MY, Liu YH, Liu TH, Chen SP, Bian XW, Guan $X Y$, Lin MC, Zeng YX et al (2012) The putative tumour suppressor microRNA-124 modulates hepatocellular carcinoma cell aggressiveness by repressing ROCK2 and EZH2. Gut 61:278-289

Zheng X, Gai XH, Ding FH, Lu ZT, Tu KS, Yao YM, Liu QG (2013) Histone acetyltransferase PCAF up-regulated cell apoptosis in hepatocellular carcinoma via acetylating histone $\mathrm{H} 4$ and inactivating AKT signaling. Mol Cancer 12:96

Zhou XL, Thorgeirsson SS, Popescu NC (2004) Restoration of DLC1 gene expression induces apoptosis and inhibits both cell growth and tumorigenicity in human hepatocellular carcinoma cells. Oncogene 23:1308-1313

Zhou L, Yang ZX, Song WJ, Li QJ, Yang F, Wang DS, Zhang N, Dou KF (2013) MicroRNA-21 regulates the migration and invasion of a stem-like population in hepatocellular carcinoma. Int $\mathrm{J}$ Oncol 43:661-669

Zhu AX, Duda DG, Sahani DV, Jain RK (2011) HCC and angiogenesis: possible targets and future directions. Nat Rev Clin Oncol 8:292-301

Zhu Y, Lu Y, Zhang Q, Liu JJ, Li TJ, Yang JR, Zeng CX, Zhuang SM (2012) MicroRNA-26a/b and their host genes cooperate to inhibit the $\mathrm{G} 1 / \mathrm{S}$ transition by activating the $\mathrm{pRb}$ protein. Nucleic Acids Res 40:4615-4625

Zondervan PE, Wink J, Alers JC, JN IJ, Schalm SW, de Man RA, van Dekken H (2000) Molecular cytogenetic evaluation of virusassociated and non-viral hepatocellular carcinoma: analysis of 26 carcinomas and 12 concurrent dysplasias. J Pathol 192:207-215 